\title{
Potent “Clicked” MMP2 Inhibitors: Synthesis, Molecular Modeling and Biological Exploration
}

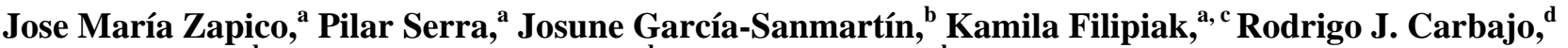 \\ Anne K. Schott, ${ }^{\mathrm{d}}$ Antonio Pineda-Lucena, ${ }^{\mathrm{d}}$ Alfredo Martínez, ${ }^{\mathrm{b}}$ Sonsoles Martín-Santamaría, ${ }^{\mathrm{a}}$ Beatriz de \\ Pascual-Teresa, ${ }^{* a}$ Ana Ramos.* ${ }^{a}$
}

\author{
Received (in $X X X, X X X)$ Xth $X X X X X X X X X 200 X$, Accepted Xth $X X X X X X X X X 200 X$ \\ First published on the web $X$ th $X X X X X X X X X 200 X$ \\ DOI: 10.1039/b000000x
}

\begin{abstract}
A new series of MMP2 inhibitors is described, following a fragment-based drug design approach.
${ }_{10}$ One fragment containing an azide group and a well known hydroxamate Zinc Binding Group in a $\alpha$-sulfone, $\alpha$-tetrahydropyrane scaffold, has been synthesized. Water-LOGSY, STD and

competition-STD experiments indicated that this fragment binds to the active site of the enzyme. A click chemistry reaction was used to connect the azide to lipophilic alkynes selected to interact selectively with the S1' subunit of MMP2, as shown by docking and molecular dynamic

15 experiments of the designed compounds. The most potent compounds $\mathbf{1 8}$ and $\mathbf{1 9}$ displayed an $\mathrm{IC}_{50}$ of 1.4 and $0.3 \mathrm{nM}$ against MMP2 respectively, and showed negligible activity towards MMP1 and MMP7, two metalloproteinases which have a shallow S1' subsite. Compound $\mathbf{1 8}$ showed also a promissing selectivity profile against some antitarget metalloproteinases, such as MMP8, and considerably less activity against MMP14 $\left(\mathrm{IC}_{50}=65 \mathrm{nM}\right)$, and MMP9 $\left(\mathrm{IC}_{50}=98 \mathrm{nM}\right)$, other MMPs 20 characterized by having a deep S1' pocket and, therefore, more similar to MMP2.
\end{abstract}

\section{Introduction}

Matrix metalloproteinases (MMPs), also called matrixins, are a family of structurally related zinc-containing enzymes that mediate the breakdown of connective tissue and are, therefore,

25 targets for therapeutic inhibitors in many inflammatory, malignant, and degenerative diseases. ${ }^{1-3}$

The vertebrates MMP family includes at least 26 enzymes, ${ }^{4}$ among which 23 have been known in humans. They are classified into six groups: Collagenases: MMP1, MMP8, 30 MMP13 and MMP18 (not present in human gene), Gellatinases: MMP2 and MMP9, Stromelysins: MMP3, MMP10 and MMP11, Matrilysin: MMP7 and MMP26, Membrane-type MMPs: MMP14 to MMP17, MMP24 and MMP25 and other MMPs.

35 Their role in the progression of cancer may involve several mechanisms. Originally, MMPs were thought to mediate invasion and metastasis primarily by matrix remodelling, thereby allowing the access of tumour cells to blood and lymphatic vessels. Evidence for this mechanism is based 40 largely on the increased invasiveness of cell lines overexpressing MMPs. More recently, it has been shown that MMPs can play a role in primary tumour growth. This involves the release of stroma-bound growth factors or MMP mediated tumour angiogenesis. Alternatively, remodelling of

45 the extracellular matrix in the vicinity of the primary tumour may provide the special requirements necessary for tumour growth. ${ }^{5}$

Effective MMP inhibitors (MMPIs) should be characterized by: 1) a functional group chelating the catalytic zinc ion (zinc50 binding group, ZBG); 2) one or more side chains undergoing strong van der Waals interactions with the the enzyme subsites, mainly with $\mathrm{S} 1$ '; and 3 ) functional groups providing additional interactions with enzyme backbone.

$\mathrm{Zn}^{2+}$-chelating hydroxamates have been the most frequently is used ZBG in MMPI design. However, binding of MMPIs is and, most importantly, selectivity have been explained by subtle interactions with key residues belonging to different subsites. ${ }^{6}$ This issue has been deeply and accurately addressed by the use of computational techniques, which have pointed to 60 the relevance of $\mathrm{S} 1$ ' subsite in the regulation of MMP selectivity. ${ }^{7}$ Thus, extensive hydrophobic interactions between the lipophilic moieties of the ligand and the S1' pocket can be largely responsible for the binding potencies. ${ }^{8}$ Moreover, a novel series of highly selective MMP13 inhibitors (pyrimidine ${ }_{65}$ dicarboxamides) ${ }^{9}$ with low nanomolar affinities, and a novel series of MMP3 inhibitors (amidinobenzisothiazoles) ${ }^{10}$ have been recently reported, which exhibite facile and extensive hydrophobic binding in the S1' pocket and no interaction with the catalytic $\mathrm{Zn}^{2+}$ ion.

70 After prolonged research, only MMP1, 2, and 7 have been experimentally validated as cancer targets. Inhibition of MMP1 has been hypothesized to be the cause of the clinically observed musculoskeletal syndrome when broad spectrum inhibitors are used. ${ }^{11,12}$ On the other hand, reduction of some 75 MMPs such as MMP3, and 8 could enhance tumorgenesis and metastasis, so their inhibition should be avoided. ${ }^{13,}{ }^{14}$ MMP9 is a tricky enzyme since its inhibition might be useful in treating patients with early-stage cancers, but MMP9 is an anti-target in patients with advanced disease. So, MMP9 80 inhibition should also been prevented. ${ }^{4}$

In this work we have focused on the design of selective MMP2 inhibitors. MMP2 plays an important role in cancer, among many other processes, by stimulating tumour growth, angiogenesis and metastasis, through its involvement on the ${ }_{85}$ degradation of extracellular matrix. It is overexpressed in 
human tumour samples and has been identified in association with highly invasive cells. For all these reasons, MMP2 has been considered for many years an important target for the design of anticancer agents. No MMPI has been licensed for 5 the treatment of cancer until date, due mainly to low selectivity, although there are many compounds in clinical development, such as the MMP2 inhibitor incyclinide, a tetracycline derivative which is being tested for cancer metastasis and solid tumours, among other indications. ${ }^{15}$

${ }_{10}$ Some series of $\alpha$-sulfone $\alpha$-piperidine and $\alpha$-tetrahydopyran hydroxamates of general structure 1, including compounds SC-78080/SD-2590 and SC-7774 (Scheme 1) have been described as potent MMP2, MMP9, and MMP13 inhibitors, while sparing MMP1. ${ }^{12,16-18}$. For this reason we have used

15 this scaffold in the design of new inhibitors, with the aim of increasing the selectivity for MMP2 over MMP9, while mantaining the MMP1 sparing character.

Our approach is based on the use of click chemistry to connect the scaffold containing the hydroxamate ZBG with 20 appropriate subunits designed on the basis of reported selective hydroxamate MMP2 inhibitors (Scheme 1, down). The $\mathrm{Cu}(\mathrm{I})$-catalyzed azide-alkyne 1,3-dipolar cycloaddition (CuAAC) has been used by several research groups for the discovery of enzyme inhibitors of acetylcholinesterase, ${ }^{19-21}$

${ }_{25} \mathrm{HIV}-1$ protease, ${ }^{22}$ carbonic anhydrase $\mathrm{II},{ }^{23}$ protein tyrosine phosphatases (PTPs), ${ }^{24}$ and caspases. ${ }^{25}$ It has also been used in an attempt to detect selective MMP inhibitors ${ }^{26}$ by the rapid assembly of a library of different succinyl hydroxamates with a series of azides, followed by in situ screening for inhibition 30 against MMP7, thermolysin and collagenase. However, they only identified two compounds with activity in the micromolar range for MMP7, inactive for thermolysin and collagenase, but without information about other MMPs.

In this work we present the design and click synthesis of a 35 new potent MMP2 and MMP3 inhibitor (18) that is 70 -fold selective against MMP9, and completely inactive against MMP1, MMP7 and MMP8. A combination of molecular modeling studies and NMR techniques has been used to reveal the potential interactions that govern the recognition and the 40 binding to MMP2 of the best inhibitors in the synthesized series, and to rationalize the structure-affinity relationships at the molecular level.

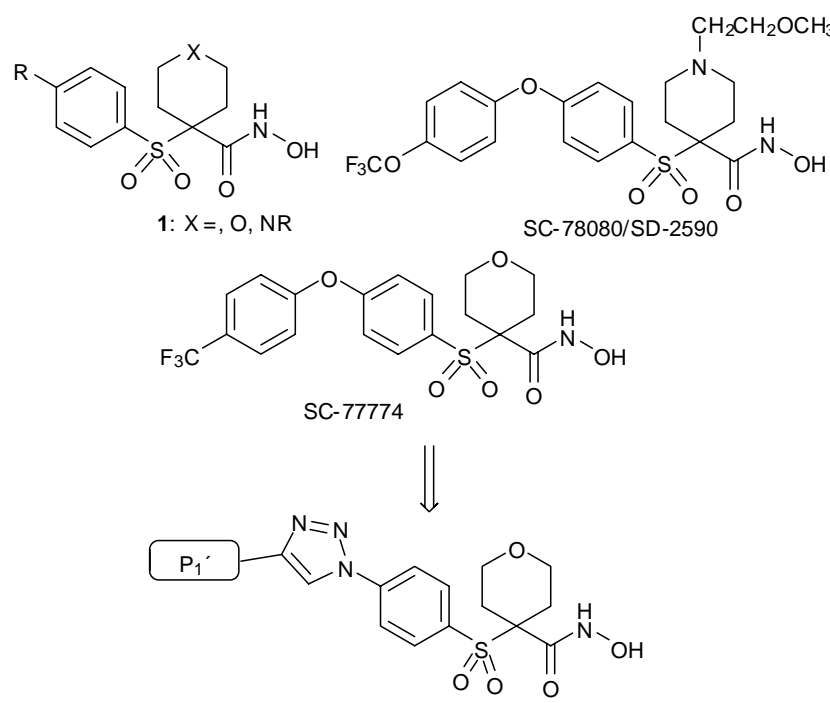

Scheme 1 General structure of MMP2 inhibitors 1 containing a tetrahydropyrane or piperidine heterocycle, structures of SC-7774 and SC-77964, and general structure of the synthesized analogues based on a 50 click synthetic approach (down).

\section{Results and Discussion}

\section{Chemistry}

A series of $\mathrm{P} 1^{\prime}$-diversified MMP2 inhibitors containing the hydroxamate ZBG (Table 1) has been synthesized, using a ${ }_{55} \mathrm{CuAAC}$ click approach, as shown in Scheme 1 . The corresponding azide contains, apart from the ZBG, an $\alpha$ tetrahydro- $2 H$-pyranyl sulfone group ( $\alpha$-THP-sulfone) capable of establishing very relevant hydrogen bond interactions with the enzyme backbone, driving the P1'group

60 into the S1'pocket. A series of P1'groups has been chosen from reported selective MMP2 inhibitors, and have been introduced in the final molecule via the corresponding alkyne. Some of the alkynes used are commercially available (Figure 1), and some had to be synthesized (Scheme 2).
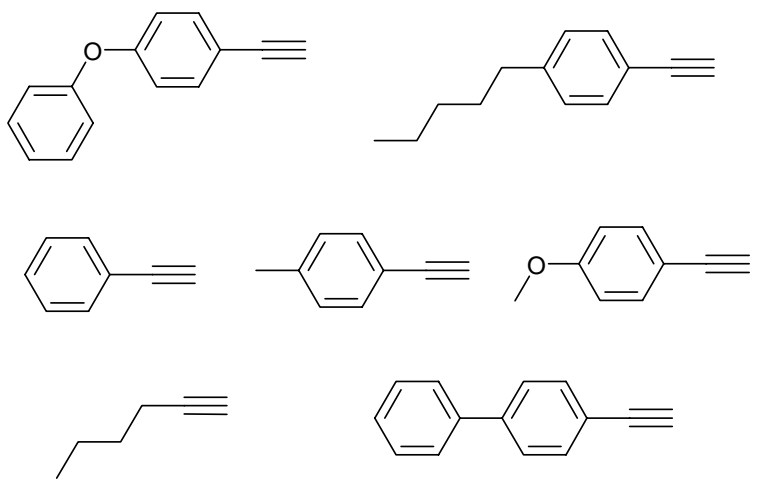

Fig. 1 Commercially available alkynes used in this work.

The detailed synthesis of the ZBG containing azide is shown in Scheme 3. Alkylation of 4-nitrobenzenethiol with methyl 270 bromoacetate gave sulphide 5, which was oxidized with oxone to afford sulfone $\mathbf{6}$. The acidic methylene was dialkylated with 
bis(2-bromoethyl)ether to afford sulfone 7. Saponification of the methyl ester with a $\mathrm{H}_{2} \mathrm{O} / \mathrm{THF}$ solution of sodium hydroxide and subsequent catalytic hydrogenation of the nitro group in $\mathbf{8}$ gave amino acid $\mathbf{9}$. This was transformed into azide ${ }_{5} \mathbf{1 0}$ by reaction with tert-butyl nitrite and azidotrimethylsilane. Coupling of the carboxylic acid with O-(tetrahydro- $2 H$ pyranyl)hydroxylamine (THP-hydroxylamine) using EDC as amide coupling agent ${ }^{16}$ gave the THP-protected hydroxamate 11, which was subsequently deprotected with a solution of ${ }_{10} \mathrm{HCl}$ in dioxane to give the desired azide $\mathbf{1 2 .}$<smiles>CCC#C[O+]=C=NS(=O)(=O)c1ccccc1</smiles><smiles>C#CCNC(=O)NS(=O)(=O)c1ccccc1</smiles><smiles>[R]c1ccc(Br)cc1</smiles><smiles>[R]c1ccc(CC#C)cc1</smiles>

Scheme 2 Synthesis of alkynes 2-4.<smiles>O=[N+]([O-])c1ccc(S)cc1</smiles><smiles>COC(=O)CSc1ccc([N+](=O)[O-])cc1</smiles><smiles>COC(=O)CS(=O)(=O)c1ccc([N+](=O)[O-])cc1</smiles>

6<smiles>CO[N+](=O)c1ccc(S(=O)(=O)C2(C(=O)O)CCOCC2)cc1</smiles>

8<smiles>Nc1ccc(S(=O)(=O)C2(C(=O)O)CCOCC2)cc1</smiles>

10<smiles>CNc1ccc(S(=O)(=O)C2(C(=O)NO)CCOCC2)cc1</smiles>

12
For the CuAAC reaction, we used the $\mathrm{Cu}(\mathrm{II}) /$ ascorbate system, and a variety of conditions were investigated. The use of catalytic amounts of $\mathrm{CuSO}_{4}(0,25-2 \mathrm{~mol} \%)$ in $t$ $\mathrm{BuOH} / \mathrm{H}_{2} \mathrm{O}$, and ascorbic acid (5-10 mol \%) brought about a 25 very slow transformation of the starting material, without apparent progress of the reaction, even after 3 days. Consequently, the amount of reactants was progressively increased, and the best results were obtained when 0.5 equivalents of $\mathrm{CuSO}_{4}$ and two equivalents of ascorbic acid 30 were used, leading to compounds 13-22 with moderate yields. Other procedures have been developed where the catalyst is introduced in the form of $\mathrm{Cu}(0),{ }^{27}$ or $\mathrm{CuI} .{ }^{25}$ Attempts to carry out the click reaction between azide $\mathbf{1 2}$ and phenylacetylene using these methodologies have been unsuccessful, and the 35 starting material was recovered unreacted, even after five days of reaction.

The $\mathrm{Cu}(\mathrm{I})$-catalyzed Huisgen 1,3-dipolar cycloaddition of azides and terminal alkynes is a regioselective process, forming exclusively the 1,4-substituted product. Accordingly, 40 we have obtained only one isomer in all CuAAC reactions, which in the case of triazole $\mathbf{1 4}$ has been characterized as the 1,4-disubstituted isomer by ${ }^{1} \mathrm{H}-\mathrm{NMR}$ (nOe) experiments (see Experimental Section).

\section{Molecular Modeling}

${ }_{45}$ For the designed compounds shown in Table 1, we first evaluated the suitability to act as MMP2 inhibitors by means of docking techniques. There are not many experimental 3D structures of MMP2 available, being PDB 1hov the only complex among MMP2 catalytic domain and an inhibitor, so hydroxamate i52 (Figure 2). Therefore, this structure was considered to perform docking studies. PDB 1 hov is an NMR structure composed of 11 models, and the superimposition of all of them showed no relevant changes around the ligand binding region. Previous studies of the binding mode of a set 55 of putative MMP2 inhibitors, including i52, showed no difference in the docking results performed on the 11 models, so we considered only model 1 to carry out the docking studies. $^{28}$

Scheme 3 Synthesis of azide 12. (a) methyl 2-bromoacetate, $\mathrm{K}_{2} \mathrm{CO}_{3}$, DMF, 98\%; (b) oxone, $\mathrm{MeOH}, \mathrm{H}_{2} \mathrm{O}, 90 \%$; (c) $\mathrm{O}\left(\mathrm{CH}_{2} \mathrm{CH}_{2} \mathrm{Br}\right)_{2}, \mathrm{~K}_{2} \mathrm{CO}_{3}$, DMAP, $\mathrm{NBu}_{4} \mathrm{I}, \mathrm{DMF}, 76 \%$; (d) $\mathrm{NaOH}, \mathrm{H}_{2} \mathrm{O} / \mathrm{THF}, 90 \%$; (e) $\mathrm{H}_{2}, \mathrm{Pd} / \mathrm{C}$, $95 \%$; (f) t-BuONO, $\mathrm{TMSN}_{3}, 94 \%$; ( g) $\mathrm{NH}_{2} \mathrm{OTHP}$, EDC, HOBT, DMAP, 20 94\%; (h) $\mathrm{HCl}$, dioxane, $91 \%$. 


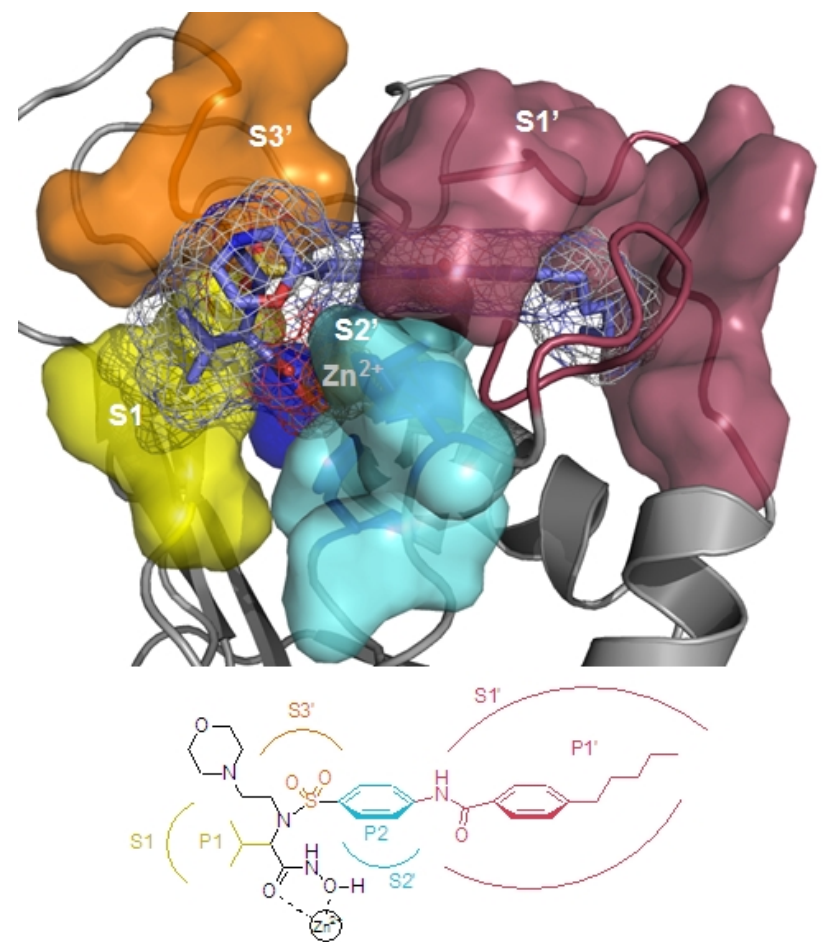

Fig. 2. Chemical structure of compound $\mathbf{1 5 2}$ showing the interactions with the main subsites of MMP2 active site.

Compounds were docked into MMP2 using different 5 approaches (see Experimental Section), combining rigid and flexible docking procedures and, in some cases, the use of two docking programs, AutoDock and Glide. The predicted binding modes for azide 12, and triazoles 13, 14, 15 (which bears the P1' group present in compound i52), 18 and 19, 10 were very similar to that of $\mathbf{i 5 2}$, that is, with the two hydroxamate oxygen atoms coordinating the catalytic $\mathrm{Zn}^{2+}$ ion, in a divalent fashion, adopting a distorted trigonal bipyramidal geometry, together with the P1' side chain inside the S1' binding pocket, and in complete agreement with the

15 experimental data relative to the MMP2-i52 complex. Final end of the P1' chain occupies a hydrophobic pocket defined by Phe148, Phe115, Leu150 and Thr145, establishing efficient hydrophobic interactions. These interactions are of great relevance for selectivity as Thr145 is an exclusive residue for ${ }_{20}$ gelatinases, while Phe148 makes MMP2 distinct from MMP9. The sulfone group perfectly mimics the sulphonamide group from i52, stablishing hydrogen bonds with the $\mathrm{NH}$ groups of Leu83 and Ala84 (S2' pocket) (Figure 3). Ala84 is highly conserved in MMPs and this interaction provides a key 25 anchorage point to the active site.

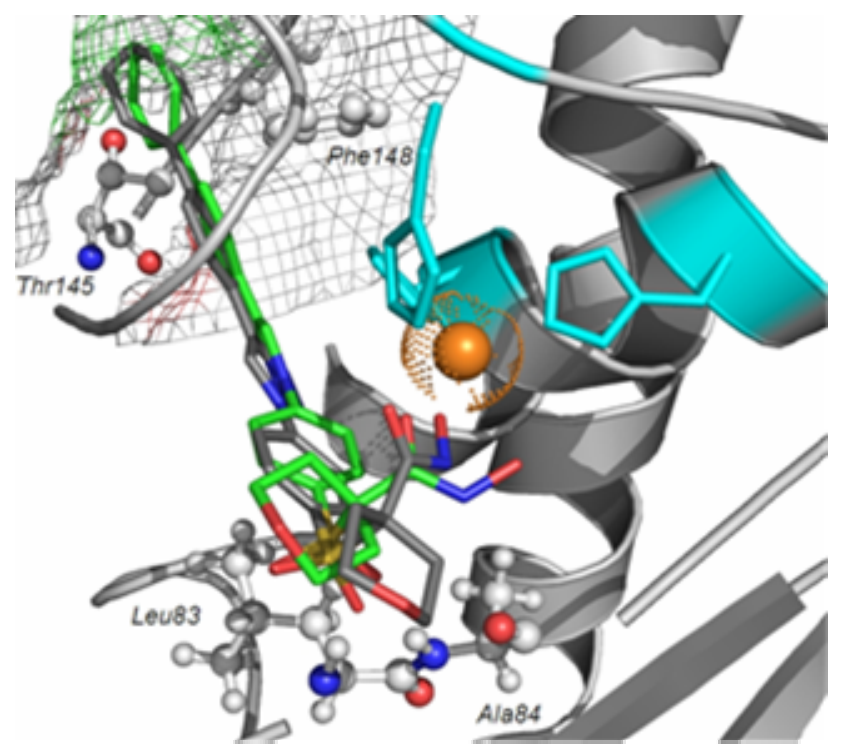

Fig. 3 The binding modes of compound $\mathbf{1 8}$ in the active site of MMP2 obtained from docking (grey), and MD simulation (green, minimized average structure for the $2 \mathrm{~ns}-2.5 \mathrm{~ns}$ interval of the MD simulation).

30 Exceptionally, for compound 17, the predicted binding pose did not show interaction between the hydroxamate group and the catalytic $\mathrm{Zn}^{2+}$ ion. The shorter length of the P1' group allows a deep entrance to the end of the S1' pocket, so the hydroxamate group establishes a hydrogen bond with $\mathrm{NH}$ 35 from Leu83 instead.

For compound 22, which is one carbon longer than 13, some docked orientations were predicted, but none of the docking procedures placed the side chain inside the S1' pocket. Also, compound 16, which is one carbon longer than 15, showed 40 predicted binding poses with the P1' group inside the S1', but none of them with $\mathrm{Zn}^{2+}$ coordination. These results suggest that the introduction of a methylene group between the triazole and the phenyl ring in the P1' group, brings about a loss of activity, most probably related to an increase of 45 flexibility that does not allow proper binding to MMP2.

Compound 21 was designed based on sulphonylurea derivative 23 (Figure 4), one of the most selective and potent MMP2 hydroxamate inhibitors found in the literature. ${ }^{29}$ For this compound AutoDock was not able to find any solution 50 within the binding site and Glide predicted one pose in which the chain is not able to occupy the final deep end of S1'. The energetically stable conformations of the sulphonylurea group orient the final phenyl ring towards a neighbour pocket defined by the alkyl $\mathrm{sp}^{3}$ carbons of Arg149 and Leu137, but 55 without establishing the efficient hydrophobic interactions that characterize the recognition inside the $\mathrm{S} 1$ ' pocket.

As it will be discussed below, compounds $\mathbf{1 8}$ and $\mathbf{1 9}$ showed the best profiles of MMP2 inhibition and MMP2 selectivity. Thus, we were prompted to carry out molecular dynamics 60 (MD) simulations of the complexes obtained from the docking studies to validate the proposed binding modes. 


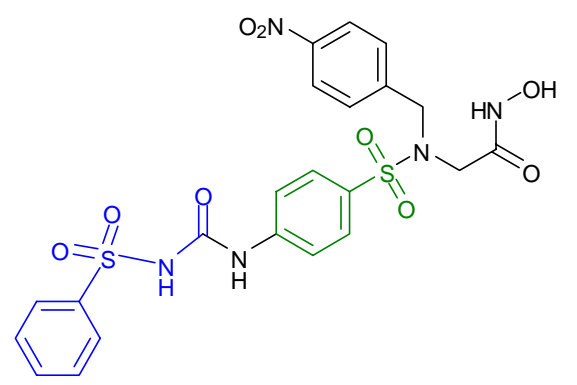

Fig. 4 Chemical structure of compound $23{ }^{29}$

Accordingly, MD simulations of both MMP2-18 and MMP2519 complexes (3 ns) were performed. Interactions of metalloproteins with ligands are often difficult to describe effectively due to the limited availability of appropriate force fields. For the treatment of zinc, we have successfully followed the "cationic dummy atom" approach used to impose 10 orientational requirements for zinc ligands, while still allowing flexibility. ${ }^{30}$ Globally, all the MMP2-ligand interactions were in agreement with the observations from the docking studies (Figures 3 and 5).

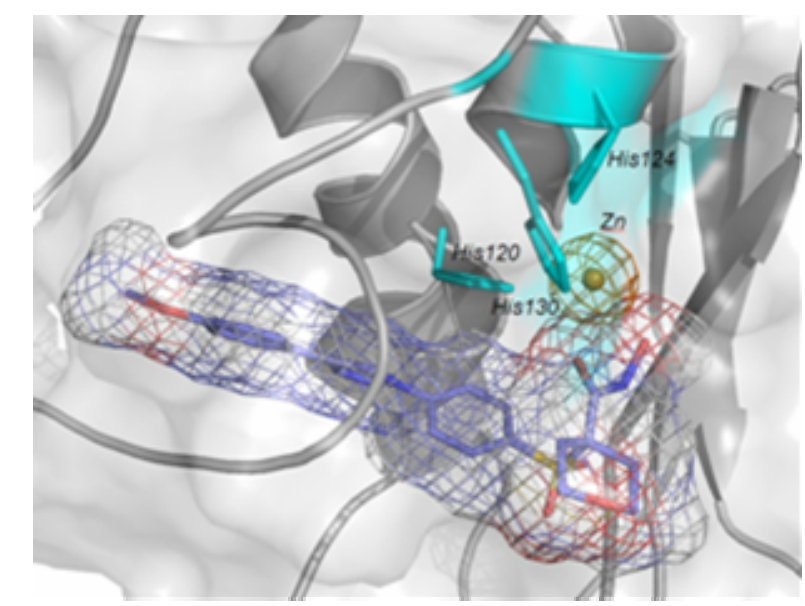

Fig. 5 Minimized average structure for the 2 ns- $2.5 \mathrm{~ns}$ interval of the MD simulation for the MMP2:19 complex.

The P1' chain occupies the S1' pocket lined with 20 hydrophobic residues Phe148, Phe115, Leu150 and Thr145. Also, it is worth mentioning that the sulfone group establishes stable hydrogen bonds with $\mathrm{NH}$ groups from Leu83 and Ala84. In the case of $\mathbf{1 9}$, the P2' phenyl ring is stacked with His 120 , while in the case of $\mathbf{1 8}$, is the triazol ring the one 25 which is interacting with His 120 . These interactions contribute to anchor the inhibitor within the MMP2 active site and, simultaneously, result in a good bidentated orientation of the hydroxamate group towards the zinc atom. This divalent coordination is maintained along the simulations supporting 30 the proposed binding mode for this novel class of MMP2 ligands (RMSD and monitored distances are available at the ESI).

\section{Biological Evaluation}

${ }_{35}$ Zymography

Zimography is a widely used technique to study extracellular matrix-degrading enzymes, such as MMPs, from tissue extracts, cell cultures, serum and urine. ${ }^{31}$ It is a simple and very sensitive technique, with a detection limit for MMP2 in 40 gelatin zymography of $10 \mathrm{pg}$, and able to identify MMPs by the degradation of their substrate. Therefore, zimography allows detecting highly potent inhibitors, with $\mathrm{IC}_{50}$ in the low picomolar range.

Inhibition of MMP2 and MMP9 activities by increasing 45 concentrations of MMPIs was measured by gelatin zymography using human serum as the source of gelatinases. The synthesized compounds were added to the digestion buffer during an overnight incubation, and zymogram bands were analyzed by densitometry. Their inhibitory activity was so compared to the one elicited by $2 R-[(4-$ biphenylsulfonyl)amino]- $N$-hydroxy-3-phenylpropinamide (BiPS), a commercially available MMP2/9 inhibitor (Table 1). Representative zymograms showing the dose-dependent inhibition of MMP2 and MMP9 activities elicited by 55 compounds 16 and $\mathbf{1 8}$ are represented in Figure 6.
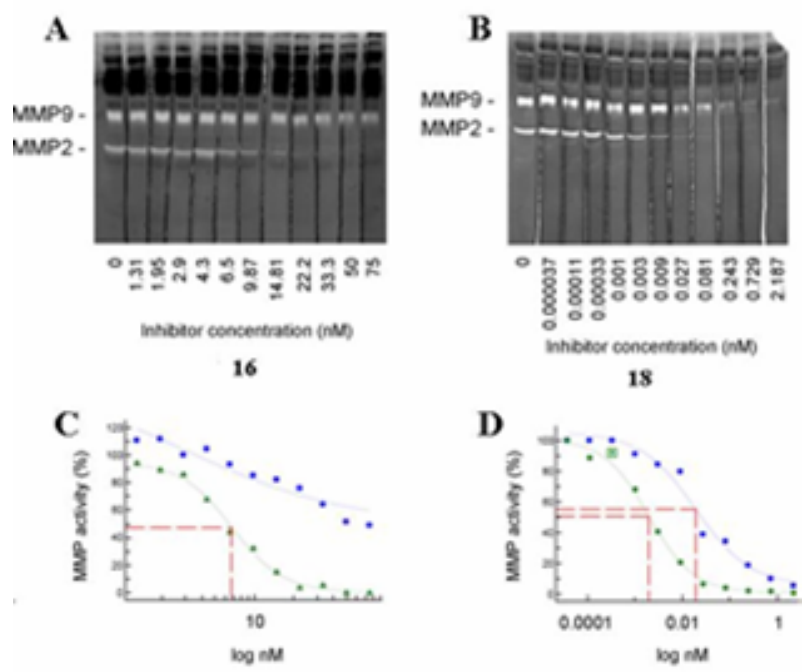

Fig. 6 Representative zymograms showing the dose-dependent inhibition of MMP2 and MMP9 activities elicited by compounds 16 (A) and 18 (B). Bands were quantified by densitometry and graphically represented to 60 obtain the $\mathrm{IC}_{50}$ value for each compound and MMP type. For compound 18 (D), the $\mathrm{IC}_{50}$ for both MMPs (green dots for MMP2, blue dots for MMP9) were calculated, whereas for $16(\mathrm{C})$ the values for MMP9 (blue dots) were too erratic and did not allow for a good calculation of the $\mathrm{IC}_{50}$ value and only the $\mathrm{IC}_{50}$ for MMP2 (green triangles) could be calculated.

65

Using this methodology all compounds were tested showing significant inhibitory activity on MMP2 and MMP9. Our results demonstrate that compounds 13-15, 17-19 inhibit MMP2 with an $\mathrm{IC}_{50}$ in the picomolar range, values which are 70 remarkably higher than those found for BiPS in the same experiment (Table 1). ${ }^{32}$

For azide 12, where the side chain is absent, the inhibition value achieved is three orders of magnitude lower, showing the key role that this group is having in the molecular 
recognition process. Compounds 16, 21 and 22 exhibited lower inhibition values than the rest of the triazoles, with $\mathrm{IC}_{50}$ in the nanomolar range, and of the same order of magnitude as the value for azide 12. These results are in agreement with the 5 docking studies that predicted that these compounds are not able to establish efficient hydrophobic interactions inside the S1' pocket (21 and 22) or only in orientations where the hydroxamate group is not coordinating the $\mathrm{Zn}^{2+}$ ion (16)

Table 1 Calculated $\mathrm{IC}_{50}$ inhibitory concentrations towards MMP2 and 10 MMP9 for compounds 12-22 and BiPS

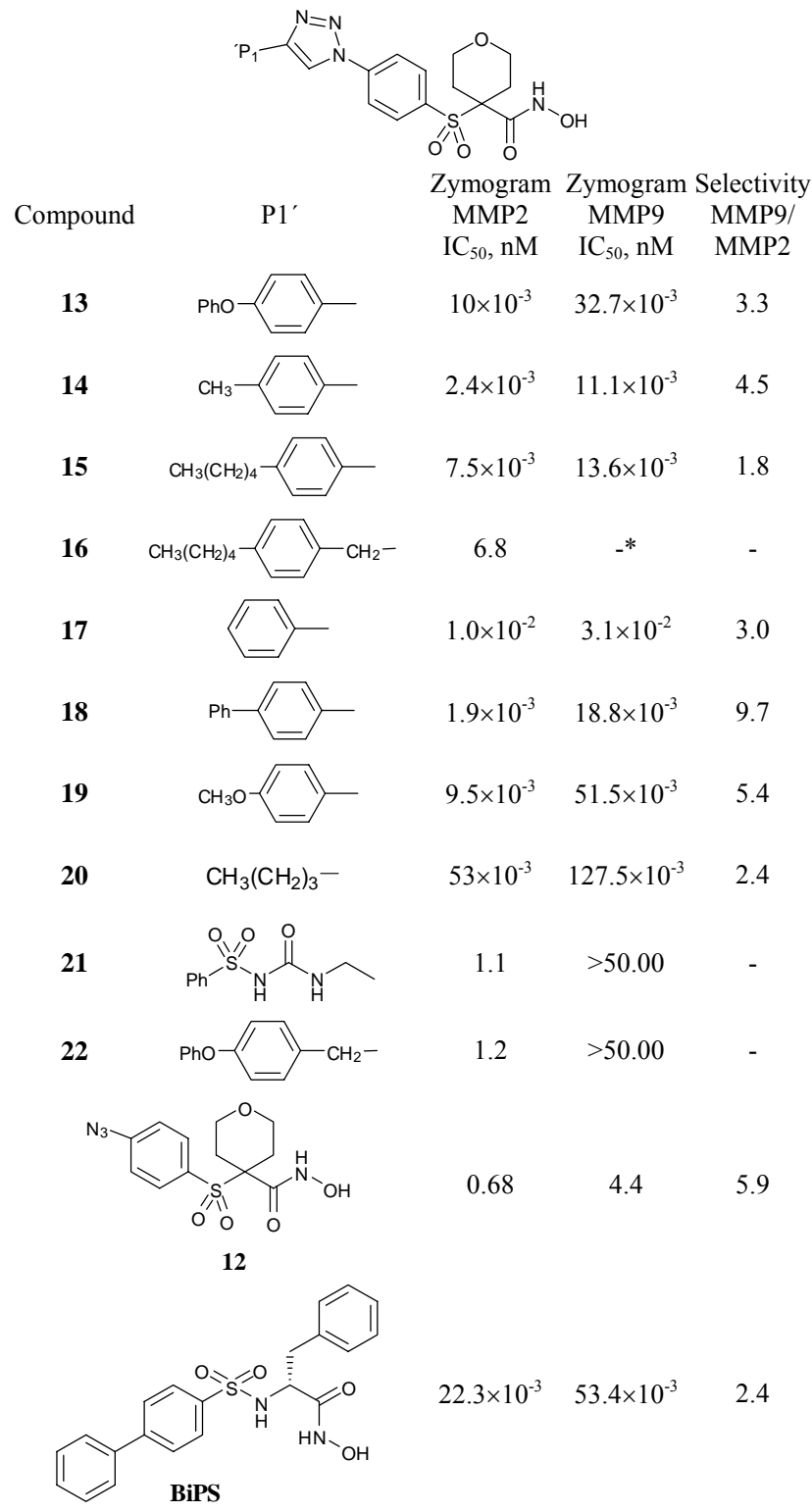

*MMP9 data behaved erratically and it was not possible to obtain a specific $\mathrm{IC}_{50}$ value. Nevertheless, MMP9 inhibition was lower than the one elicited on MMP2, as shown in figure $6 \mathrm{~A}$

15 Specific MMP2 $\mathrm{IC}_{50}$ values of all compounds tested were lower than the corresponding values for MMP9, putting forward a promising MMP2/MMP9 selectivity profile. Tacking into account these interesting results, we then proceeded to select the most active and selective compounds
20 (18 and 19) in order to submit them to a complete MMP inhibitory profile.

\section{MMPs inhibition profile.}

Compounds 18 and 19 were selected to carry out studies of ${ }_{25}$ selectivity in a panel of ten different MMPs to obtain a complete inhibitory profile. The two compounds were tested in a MMP Inhibitor Profiling Kit (Enzo Life Science, Inc), which allows the quantitative measurement of MMP inhibition and was used as described in the Experimental Section.

30 Table 2 reports MMP inhibitory activities of these compounds as $\mathrm{IC}_{50}$ values. Both $\mathbf{1 8}$ and $\mathbf{1 9}$ show potency as MMP2 and MMP13 inhibitors in the low nanomolar range. Compound $\mathbf{1 8}$ showed an $\mathrm{IC}_{50}=1.4 \mathrm{nM}$ towards $\mathrm{MMP} 2$, and $\mathrm{IC}_{50}=0.9 \mathrm{nM}$ towards MMP13, and selectivity over MMP1 and MMP7. The 35 negligible activity of these inhibitors against MMP-1 and MMP-7 is not unexpected. They have been designed to interact with MMP-2, an enzyme characterized by a large adaptable S1' pocket, while MMP-1 and MMP-7 display short and narrow S1' pockets. ${ }^{33,}{ }^{34}$ Moreover, 18 is also selective 40 versus MMP8 and shows a reduced activity against MMP14 $\left(\mathrm{IC}_{50}=65 \mathrm{nM}\right)$, and MMP9 $\left(\mathrm{IC}_{50}=98 \mathrm{nM}\right)$, other MMPs characterized by having a deep S1' pocket and, therefore, more similar to MMP2. The introduction of the rigid biphenyl moiety attached to the triazole subunit, together with the 45 proper length and hydrophobic character of $\mathrm{P} 1$ ' may be favouring the interaction with the deep hydrophobic S1' pocket, leading to high inhibitory potency and selectivity for MMP2 and MMP13.

Compound 19, where the rigid biphenyl has been replaced by 50 the more flexible $p$-methoxyphenyl unit, also exhibits an increased potency with $\mathrm{IC}_{50}$ values for MMP2 of $0.3 \mathrm{nM}$. However, while selectivity versus MMP1 is similar to that shown for 18, the selectivity versus the rest of the MMPs is diminished.

Table 2 Inhibitory activity of compounds $\mathbf{1 8}$ and $\mathbf{1 9}$ towards selected MMPs

$\begin{array}{ccc} & \begin{array}{c}\text { Compound 18 } \\ \mathbf{I C}_{\mathbf{5 0}}, \mathbf{n M}^{\mathbf{a}}\end{array} & \begin{array}{c}\text { Compound 19 } \\ \mathbf{I C}_{\mathbf{5 0}}, \mathbf{n M}^{\mathbf{a}}\end{array} \\ \text { MMP1 } & >1000 & >1000 \\ \text { MMP2 } & 1.4 & 0.3 \\ \text { MMP3 } & 17.2 & 9.6 \\ \text { MMP7 } & >100 & 70 \\ \text { MMP8 } & >100 & 6.1 \\ \text { MMP9 } & 98 & 11.3 \\ \text { MMP10 } & 51 & 7.8 \\ \text { MMP12 } & 3.2 & 1.2 \\ \text { MMP13 } & 0.9 & 1.4 \\ \text { MMP14 } & 65 & 8.2\end{array}$

${ }^{\text {a }}$ Concentration required for $50 \%$ inhibition of enzyme activity. Standard deviations are less than $10 \%$ of mean values in three experiments

60

\section{NMR studies}

NMR is a very powerful biophysical technique to study protein-ligand interactions and, in addition to the analysis of binding events, it can provide relevant structural information. ${ }_{65}$ Also, NMR is very sensitive when analysing weak intermolecular interactions. In the current study, two complementary ligand-based NMR techniques covering a 
wide range of binding affinities, water-LOGSY ${ }^{35}$ and STD (Saturation Transfer Difference) $^{36}$ have been used. These NMR experiments are designed to evaluate the effect on the ligand upon binding to the protein, which is not required in 5 large amounts nor isotopically labelled. To improve the stability of the recombinantly expressed catalytic domain of $\mathrm{MMP}^{37}$ and prevent auto-proteolytic activity, it was necessary to mutate the active site glutamic acid to glutamine, as shown by Rowsell et al. ${ }^{38}$ This conservative mutation does 10 not affect inhibitor binding in the active site.

All compounds shown in table 1 were tested for binding to MMP2 by NMR, and competition experiments were recorded using BiPS, as a positive control. Figure 7 shows the waterLOGSY, STD and competition-STD spectra acquired for the 15 azide fragment $\mathbf{1 2}$ containing the hydroxamate ZBG. Both water-LOGSY and STD yield unambiguous positive results. The decrease in the intensity of the signals for $\mathbf{1 2}$ in the STD experiment acquired in the presence of BiPS inhibitor, indicates that both molecules bind to the same site on MMP2.

20 These experimental results are in complete agreement with our docking predictions, demonstrating the appropriate selection of the azide fragment to carry out fragment-based drug design. Attachment of carefully selected alkynes has led to compounds 13-22 which were also submitted to the same 25 NMR experiments.

Compounds 20 and 21 showed positive results in the interaction with MMP2 and in the competition experiments. Compounds 14, 17, 19 and 22 showed positive results in the NMR binding experiments, although their competition assays

30 did not provide conclusive results due to the low solubility of the compounds in water. The rest of the molecules could not be assayed by NMR, not even after the addition of up to $10 \%$ DMSO to improve the solubility of the sample.

STD experiments can provide structural information by 35 identifying the epitope of the molecule interacting with the protein, as its signals will see a relatively larger increase in intensity compared to those signals belonging to a region of the molecule not directly involved in the binding interaction. However, from the analysis of the interaction experiments of 40 12, 20 and 21, we could not find a region showing a binding preponderance over the rest.

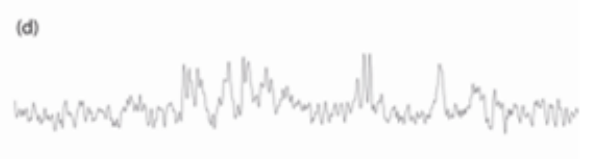

(c)

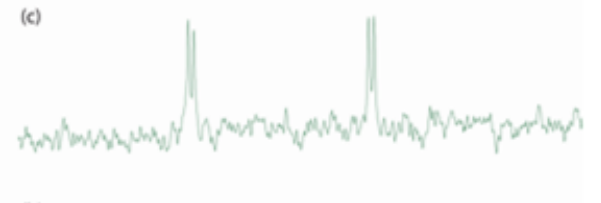

(b)
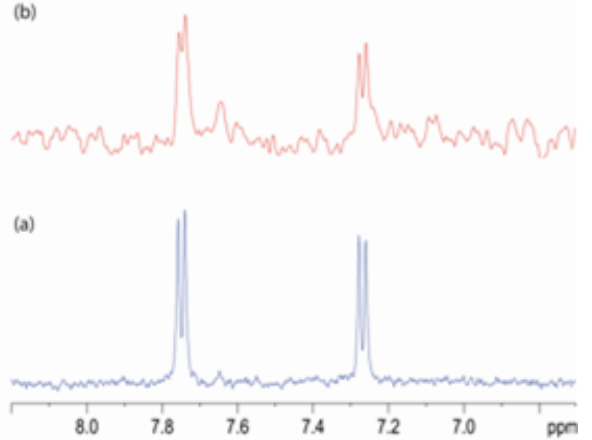

Fig. 7 NMR binding experiments of MMP2 with fragment 12. (a) Aromatic proton region of the monodimensional ${ }^{1} \mathrm{H}$ NMR of MMP2 (5 $45 \mu \mathrm{M})$ and $12(100 \mu \mathrm{M})$. At this protein concentration the signals from MMP2 are not observed. (b) Water-LOGSY and (c) STD experiments show positive signals from the ligand, thus proving the interaction between the protein and 12. (d) Competition STD experiment after the addition of $200 \mu \mathrm{M}$ BiPS. The reduction of the signals compared to 50 spectrum (c) indicates that both 12 and BiPS bind to the same MMP2 site. The extra signals on the spectrum correspond to the BiPS molecule.

\section{Conclusions}

A series of $\alpha$-sulfone, $\alpha$-tetrahydropyrane hydroxamates was designed based on data from the literature about selective 55 MMP2/MMP9 inhibitors, and exploiting the potential of click chemistry in a fragment based drug design approach. One of the designed fragments contains a hydroxamate $\mathrm{ZBG}$, and its ability to bind the active site of the enzyme was demonstrated by water-LOGSY and STD NMR experiments. A CuAAC 60 reaction was used to connect the ZBG fragment bearing an azide to several carefully selected hydrophobic alkynes. These alkynes were chosen to selectively interact with the hydrophobic S1' pocket of MMP2. The obtained compounds were evaluated as MMP2 and MMP9 inhibitors in a gelatin ${ }_{65}$ zymography using human serum as the source of gelatinases and in a colorimetric assay against a pannel of ten MMPs. Among the novel inhibitors, compound 18 presented a promising profile, with low nanomolar activity against MMP2 and MMP13, negligible activity towards MMP1 and MMP7, 70 and a 70-fold higher activity compared to MMP9. It also showed lower activity against MMP10 and MMP14. Docking, molecular dynamics simulations and NMR experiments have been used to analyze the mode of binding and to rationalize the structure-affinity relationships at the molecular level.

75 The described fragment-based design has proved to be a useful method to detect highly MMP2 active inhibitors, selective over MMP1, with a promissing selectivity profile against some antitarget metalloproteinases, such as MMP8, and considerably less activity against MMP9. This approach, 
together with the information obtained from the computational study, is currently being used in the design of new inhibitors making use of different ZBGs. The lack of water solubility of these compounds could preclude its use in clinic. Current 5 work is directed towards the introduction of basic groups which could improve their pharmacokinetic properties.

Additionally, this approach is especially attractive as it permits the desing and efficient synthesis of inhibitors with improved selectivity for one or another MMP by a careful 10 selection of the appropriate alkynes.

\section{Experimental Section}

\section{Chemistry}

General procedures. Melting points (uncorrected) were 15 determined on a Stuart Scientific SMP3 apparatus. Infrared (IR) spectra were recorded with a Perkin-Elmer 1330 infrared spectrophotometer. ${ }^{1} \mathrm{H}$ and ${ }^{13} \mathrm{C}$ NMR data were recorded on a Bruker 300-AC instrument. Chemical shifts $(\delta)$ are expressed in parts per million relative to internal tetramethylsilane; 20 coupling constants $(J)$ are in hertz. Mass spectra were run on a Bruker Esquire 3000 spectrometer. Elemental analyses $(\mathrm{C}, \mathrm{H}$, $\mathrm{N})$ were performed on a LECO CHNS-932 apparatus at the Microanalyses Service of the University Complutense of Madrid; unless otherwise stated, all reported values are within $25 \pm 0.4 \%$ of the theoretical compositions. Thin-layer chromatography (TLC) was run on Merck silica gel 60 F-254 plates. Unless stated otherwise, starting materials used were high-grade commercial products.

$\mathrm{N}$-(Prop-2-yn-1-ylcarbamoyl)benzenesulfonamide (2). To a 30 solution of propargylamine $(1,48 \mathrm{~g}, 26,38 \mathrm{mmol})$ in anhydrous $\mathrm{CH}_{3} \mathrm{CN}\left(40 \mathrm{~cm}^{3}\right)$ was added, under argon, benzenesulfonyl isocyanate $(5,09 \mathrm{~g}, 26,38 \mathrm{mmol})$. After strirring at room temperature overnight, the reaction mixture was concentrated under vacuum, and the obtained solid was recrystallized from 35 AcOEt to give $2(5,47 \mathrm{~g}, 87 \%)$ as a white solid, mp 161.8$163.6{ }^{\circ} \mathrm{C} . v_{\max }(\mathrm{KBr}) / \mathrm{cm}^{-1} 3354,3269,2125,1705,1667 ; \delta_{\mathrm{H}}$ $\left(\mathrm{DMSO}-d_{6}\right) 3.10(1 \mathrm{H}, \mathrm{t}, J 2.4, \mathrm{C} \equiv \mathrm{CH}), 3.74(2 \mathrm{H}, \mathrm{dd}, J 2.4$ and 5.5, $\left.\mathrm{CH}_{2}\right), 6.92\left(1 \mathrm{H}, \mathrm{t}, J 5.49, \mathrm{~N} H-\mathrm{CH}_{2}\right), 7.59-7.71(3 \mathrm{H}, \mathrm{m}$, $\mathrm{ArH}), 7.89-7.92(2 \mathrm{H}, \mathrm{m}, \mathrm{ArH}), 10.9\left(1 \mathrm{H}\right.$, br s, $\left.\mathrm{SO}_{2} \mathrm{NH}\right) ; \delta_{\mathrm{C}}$ $40\left(\mathrm{DMSO}-d_{6}\right)$ 28.9, 73.2, 81.1, 127.3, 129.1, 133.3, 140.2, 151.3. MS (ESI): $m / z 260.96[\mathrm{M}+\mathrm{Na}]^{+}$.

1-Pentyl-4-(prop-2-yn-1-yl)benzene (3). A portion $\left(1 \mathrm{~cm}^{3}\right)$ of a solution of 1-bromo-4-pentylbenzene $(3,00 \mathrm{~g}, 12,81 \mathrm{mmol})$ in anhydrous THF $\left(10 \mathrm{~cm}^{3}\right)$ was added to a mixture of 45 magnesium turnings $(0,34 \mathrm{~g}, 14,04 \mathrm{mmol})$ and iodine $(10 \mathrm{mg})$ in anhydrous THF $\left(2 \mathrm{~cm}^{3}\right)$ under argon. When the Grignard reaction began, and after addition of $10 \mathrm{~cm}^{3}$ of dry THF, the remaining solution of aryl bromide was added dropwise. The reaction mixture was refluxed for $2 \mathrm{~h}$. After cooling to room so temperature, magnesium rests were removed by filtration via cannula. To the resulting solution was added (3-bromoprop-1ynyl)trimethylsilane $(2,00 \mathrm{~g}, 10,25 \mathrm{mmol})$ and the mixture was refluxed for $12 \mathrm{~h}$, cooled and concentrated under vacuum. A solution of $1 \mathrm{~N} \mathrm{HCl}\left(50 \mathrm{~cm}^{3}\right)$ was added and the crude was 55 extracted with $\mathrm{Et}_{2} \mathrm{O}$. The organic extracts were dried $\left(\mathrm{MgSO}_{4}\right)$, filtered and evaporated to dryness. The residue was chromatographed on silica gel using hexane as eluent to obtain trimethyl-[3-(4-pentylphenyl)prop-1-ynyl]silane as a colourless oil $(708 \mathrm{mg}, 21 \%) \cdot v_{\max } / \mathrm{cm}^{-1} 2165 ; \delta_{\mathrm{H}}\left(\mathrm{CDCl}_{3}\right)$ $600.20\left(9 \mathrm{H}, \mathrm{s}, \mathrm{Si}\left(\mathrm{CH}_{3}\right)_{3}\right), 0.90\left(3 \mathrm{H}, \mathrm{t}, J\right.$ 6.8, $\left.\mathrm{CH}_{3}\right), 1.29-1.38$ (4H, m, $\left.\mathrm{CH}_{2} \mathrm{CH}_{2} \mathrm{CH}_{3}\right), 1.56-1.66\left(2 \mathrm{H}, \mathrm{m}, \mathrm{ArCH}_{2} \mathrm{CH}_{2}\right), 2.60$ $\left(2 \mathrm{H}, \mathrm{t}, J\right.$ 7.8, $\left.\mathrm{ArCH}_{2} \mathrm{CH}_{2}\right), 3.64\left(2 \mathrm{H}, \mathrm{s}, \mathrm{C} \equiv \mathrm{C}_{-} \mathrm{CH}_{2}\right), 7.15(2 \mathrm{H}$, d, $J$ 8.3, $\mathrm{ArH}), 7.26(2 \mathrm{H}, \mathrm{d}, J 8.3, \mathrm{ArH}) ; \delta_{\mathrm{C}}\left(\mathrm{CDCl}_{3}\right) 0.1,14.0$, 22.6, 25.7, 31.3, 31.5, 35.5, 86.5, 104.6, 127.7, 128.5, 133.4, 65141.1 .

To a solution of the TMS-protected alkyne $(618 \mathrm{mg}, 2,39$ $\mathrm{mmol})$ in EtOH $\left(10 \mathrm{~cm}^{3}\right)$ was added dropwise a solution of silver nitrate $(609 \mathrm{mg}, 3,59 \mathrm{mmol})$ in water $\left(3 \mathrm{~cm}^{3}\right)$ and EtOH $\left(7 \mathrm{~cm}^{3}\right)$. The solution was stirred at room temperature for 30 $70 \mathrm{~min}$ and then, a solution of and $\mathrm{KCN}(1,58 \mathrm{~g}, 23,91 \mathrm{mmol})$ in water $\left(3 \mathrm{~cm}^{3}\right)$ was added. The mixture was extracted with $\mathrm{Et}_{2} \mathrm{O}$, the organic extracts were washed with water and brine, dried $\left(\mathrm{MgSO}_{4}\right)$ and evaporated to dryness. The residue was purified by column chromatography on silica gel, using 75 hexane as eluent to afford 3 as a colourless oil (430 mg, 97\%) which decomposes on standing. $v_{\max } / \mathrm{cm}^{-1} 2115 ; \delta_{\mathrm{H}}\left(\mathrm{CDCl}_{3}\right)$ $0.92\left(3 \mathrm{H}, \mathrm{t}, J\right.$ 6.4, $\left.\mathrm{CH}_{3}\right), 1.29-1.36\left(4 \mathrm{H}, \mathrm{m}, \mathrm{CH}_{2} \mathrm{CH}_{2} \mathrm{CH}_{3}\right)$, 1.56-1.67 (2H, m, $\left.\mathrm{ArCH}_{2} \mathrm{CH}_{2}\right), 2.20(1 \mathrm{H}, \mathrm{t}, J 2.9, \mathrm{C} \equiv \mathrm{CH})$, $2.61\left(2 \mathrm{H}, \mathrm{t}, J 7.3, \mathrm{ArCH}_{2} \mathrm{CH}_{2}\right), 3.60\left(2 \mathrm{H}, \mathrm{d}, J 2.9, \mathrm{C} \equiv \mathrm{C}-\mathrm{CH}_{2}\right)$, $807.16(2 \mathrm{H}, \mathrm{d}, J 7.8, \mathrm{ArH}), 7.29(2 \mathrm{H}, \mathrm{d}, J 7.8, \mathrm{ArH}) ; \delta_{\mathrm{C}}\left(\mathrm{CDCl}_{3}\right)$ $14.0,22.5,24.3,31.2,31.4,35.4,70.2,82.1,127.6,128.5$, 133.1, 141.2.

1-Phenoxy-4-(prop-2-yn-1-yl)benzene (4). The procedure described above was used for the synthesis of 4. From 185 bromo-4-phenoxybenzene (4,00 g, 16,06 mmol), magnesium turnings $(0,42 \mathrm{~g}, 17,29 \mathrm{mmol})$, iodine $(10 \mathrm{mg})$ and (3-bromo1-propynyl)trimethylsilane (2,36 g, 12,35 $\mathrm{mmol})$, and after chromatography using hexane:DCM (95:5) as eluent trimethyl-[3-(4-phenoxyphenyl)prop-1-ynyl]silane was 90 produced as a colourless oil $(1,15 \mathrm{~g}, 33 \%)$, which decomposes on standing. $v_{\max } / \mathrm{cm}^{-1} 2160 ; \delta_{\mathrm{H}}\left(\mathrm{CDCl}_{3}\right) 0.28(9 \mathrm{H}, \mathrm{s}$, $\left.\mathrm{Si}\left(\mathrm{CH}_{3}\right)_{3}\right), 3.71\left(2 \mathrm{H}, \mathrm{s}, \mathrm{C} \equiv \mathrm{C}-\mathrm{CH}_{2}\right), 7.03-7.09(4 \mathrm{H}, \mathrm{m}, \mathrm{ArH})$, 7.13-7.19 (1H, m, ArH), 7.36-7.39 (4H, m, ArH); $\delta_{\mathrm{C}}\left(\mathrm{CDCl}_{3}\right)$ $0.1,25.4,86.9,104.3,118.6,119.0,123.1,129.1,129.7$, $95131.1,155.8,157.3$.

From trimethyl-[3-(4-phenoxyphenyl)prop-1-ynyl]silane $(1,15$ $\mathrm{g}, 4,10 \mathrm{mmol}), \mathrm{AgNO}_{3}(1,05 \mathrm{~g}, 6,15 \mathrm{mmol})$ and $\mathrm{KCN}(2,67 \mathrm{~g}$, $41,01 \mathrm{mmol}$ ) and after column chromatography using hexane:DCM $(9: 1)$ as eluent, 4 was produced as a colourless 100 oil $(734 \mathrm{mg}, 86 \%)$ which decomposes on standing. $\delta_{\mathrm{H}}\left(\mathrm{CDCl}_{3}\right)$ $2.22(1 \mathrm{H}, \mathrm{t}, J 2.9, \mathrm{CH}), 3.61\left(2 \mathrm{H}, \mathrm{d}, J 2.9, \mathrm{CH}_{2}\right), 6.97-7.04$ $(4 \mathrm{H}, \mathrm{m}, \mathrm{ArH}), 7.08-7.14(1 \mathrm{H}, \mathrm{m}, \mathrm{ArH}), 7.31-7.36(4 \mathrm{H}, \mathrm{m}$, $\mathrm{ArH}) ; \delta_{\mathrm{C}}\left(\mathrm{CDCl}_{3}\right) 24.0,70.5,81.2,118.6,119.1,123.1,129.1$, 129.7, 130.9, 155.8, 157.3.

105 Methyl [(4-nitrophenyl)sulfanyl]acetate (5). To a solution of 4-nitrobenzenethiol $(5.05 \mathrm{~g}, 26.01 \mathrm{mmol})$ in DMF $\left(50 \mathrm{~cm}^{3}\right)$ at $0{ }^{\circ} \mathrm{C}$ was added $\mathrm{K}_{2} \mathrm{CO}_{3}(5.39 \mathrm{~g}, 39.02 \mathrm{mmol})$. The reaction was stirred for $15 \mathrm{~min}$ at $0{ }^{\circ} \mathrm{C}$ and methyl bromoacetate $(2.65$ $\mathrm{cm}^{3}, 28.62 \mathrm{mmol}$ ) was added. The reaction mixture was 110 stirred overnight at room temperature and then diluted with ethyl acetate $\left(200 \mathrm{~cm}^{3}\right)$ and washed successively with saturated aqueous $\mathrm{NH}_{4} \mathrm{Cl}$ and brine. The extract was dried $\left(\mathrm{MgSO}_{4}\right)$, filtered and evaporated to dryness, and the residue which was chromatographed on silica gel (hexane/AcOEt 
$85: 15)$ to give $5(5.80 \mathrm{~g}, 98 \%)$ as a white solid, $\mathrm{mp}$ 69.8-71.2 ${ }^{\circ} \mathrm{C}$ (EtOH). (Found: C, 47.43; H, 3.93; N, 6.78; S, 14.30 . $\mathrm{C}_{9} \mathrm{H}_{9} \mathrm{NO}_{4} \mathrm{~S}$ requires $\mathrm{C}, 47.57 ; \mathrm{H}, 3.99 ; \mathrm{N}, 6.16 ; \mathrm{S}, 14.11 \%$ ); $v_{\max }(\mathrm{KBr}) / \mathrm{cm}^{-1} 1724 ; \delta_{\mathrm{H}}\left(\mathrm{CDCl}_{3}\right) 3.78\left(3 \mathrm{H}, \mathrm{s}, \mathrm{OCH}_{3}\right), 3.80$ ${ }_{5}\left(2 \mathrm{H}, \mathrm{s}, \mathrm{CH}_{2}\right), 7.43(2 \mathrm{H}, \mathrm{d}, J=8.8, \operatorname{ArH}), 8.16(2 \mathrm{H}, \mathrm{d}, J=8.8$, $\mathrm{ArH}) ; \delta_{\mathrm{C}}\left(\mathrm{CDCl}_{3}\right)$ 34.2, 53.0, 124.0, 126.6, 145.3, 145.6, 169.1; MS (ESI): $m / z 249.93[\mathrm{M}+\mathrm{Na}]^{+}$.

Methyl [(4-nitrophenyl)sulfonyl]acetate (6). To a solution of $5(5.72 \mathrm{~g}, 25.17 \mathrm{mmol})$ in $\mathrm{MeOH}\left(50 \mathrm{~cm}^{3}\right)$ and water $(5$ $10 \mathrm{~cm}^{3}$ ), was added Oxone ${ }^{\circledR}$ (potassium hydrogen persulfate) (38.69 g $62.93 \mathrm{mmol}$ ) at $0{ }^{\circ} \mathrm{C}$. After stirring at room temperature for $2 \mathrm{~h}$, the crude reaction was filtered and the solid washed with $\mathrm{MeOH}$. The solution was concentrated in vacuo, solved in AcOEt, washed with saturated aqueous ${ }_{15} \mathrm{NaHCO}_{3}$ and brine. The extract was dried $\left(\mathrm{MgSO}_{4}\right)$, filtered and evaporated to dryness, to give $6(5.84 \mathrm{~g}, 90 \%)$ as a yellowish solid, $\mathrm{mp} 130.3-131.8{ }^{\circ} \mathrm{C}$ (AcOEt). (Found: $\mathrm{C}$, $41.74 ; \mathrm{H}, 3.50 ; \mathrm{N}, 5.81 ; \mathrm{S}, 12.47 . \mathrm{C}_{9} \mathrm{H}_{9} \mathrm{NO}_{6} \mathrm{~S}$ requires $\mathrm{C}$, $41.70 ; \mathrm{H}, 3.54 ; \mathrm{N}, 5.40 ; \mathrm{S}, 12.37 \%) ; v_{\max }(\mathrm{KBr}) / \mathrm{cm}^{-1} 1740$; ${ }_{20} \delta_{\mathrm{H}}\left(\mathrm{CDCl}_{3}\right) 3.75\left(3 \mathrm{H}, \mathrm{s}, \mathrm{OCH}_{3}\right), 4.21\left(2 \mathrm{H}, \mathrm{s}, \mathrm{CH}_{2}\right), 8.18(2 \mathrm{H}$, d, $J 8.8, \mathrm{ArH}), 8.46(2 \mathrm{H}, \mathrm{d}, J 8.8, \mathrm{ArH}) ; \delta_{\mathrm{C}}\left(\mathrm{CDCl}_{3}\right) 53.4$, $60.4,124.4,130.3,143.9,151.1,162.4$; MS (ESI): $m / z 281.95$ $[\mathrm{M}+\mathrm{Na}]^{+}$.

Methyl 4-[(4-nitrophenyl)sulfonyl]tetrahydro-2H-pyran-425 carboxylate (7). To a solution of $6(3.00 \mathrm{~g}, 11.57 \mathrm{mmol})$ in DMF $\left(30 \mathrm{~cm}^{3}\right)$ at $0{ }^{\circ} \mathrm{C}$ was added $\mathrm{K}_{2} \mathrm{CO}_{3}(4.00 \mathrm{~g}, 28.93$ $\mathrm{mmol})$. The reaction mixture was stirred for $15 \mathrm{~min}$ at room temperature and bis-(2-bromoethyl)ether (2.95 g,12.73 mmol), DMAP (85 mg, $0.69 \mathrm{mmol})$ and tetra- $n$-butylammonium 30 iodide $(256 \mathrm{mg}, 0.69 \mathrm{mmol})$ were added. Then the mixture was stirred at room temperature $24 \mathrm{~h}$ and poured into $1 \mathrm{~N} \mathrm{HCl}$ $\left(100 \mathrm{~cm}^{3}\right)$. The solid obtained was filtered, washed with hexane to give 7 as a pale yellow solid (4.66 g, 76\%) after recrystallization, $\mathrm{mp}$ 192.8-194.6 ${ }^{\circ} \mathrm{C}$ (AcOEt). (Found: $\mathrm{C}$, ${ }_{35} 47.47 ; \mathrm{H}, 4.56 ; \mathrm{N}, 4.51 ; \mathrm{S}, 9.66 . \mathrm{C}_{13} \mathrm{H}_{15} \mathrm{NO}_{7} \mathrm{~S}$ requires $\mathrm{C}$ $47.41 ; \mathrm{H}, 4.59 ; \mathrm{N}, 4.25 ; \mathrm{S}, 9.74 \%) ; v_{\max }(\mathrm{KBr}) / \mathrm{cm}^{-1} 3104$, 2967, 2867, 1739; $\delta_{\mathrm{H}}\left(\mathrm{CDCl}_{3}\right) 2.20-2.34\left(4 \mathrm{H}, \mathrm{m}, 2 \mathrm{CH}_{2}\right), 3.29$ $(2 \mathrm{H}, \mathrm{td}, J 12.2,3.4,2 \mathrm{OCH} H), 3.81\left(3 \mathrm{H}, \mathrm{s}, \mathrm{CH}_{3}\right), 4.01-4.07$ $(2 \mathrm{H}, \mathrm{m}, 2 \mathrm{OCH} H), 8.00(2 \mathrm{H}, \mathrm{d}, J 8.8, \mathrm{ArH}), 8.42(2 \mathrm{H}, \mathrm{d}, J 8.8$ $\left.{ }_{40} \mathrm{~Hz}, \mathrm{ArH}\right) ; \delta_{\mathrm{C}}\left(\mathrm{CDCl}_{3}\right)$ 28.0, 53.6, 64.6, 72.2, 123.9, 131.7, 140.6, 151.2, 167.2; MS (ESI): $m / z 352.06[\mathrm{M}+\mathrm{Na}]^{+}$.

4-[(4-Nitrophenyl)sulfonyl]tetrahydro-2H-pyran-4-

carboxylic acid (8). To a solution of $7(3.94 \mathrm{~g}, 11.96 \mathrm{mmol})$ in THF $\left(40 \mathrm{~cm}^{3}\right)$ was added $1 \mathrm{~N} \mathrm{NaOH}\left(120 \mathrm{~cm}^{3}\right)$ and the

45 mixture was stirred at room temperature for $4 \mathrm{~h}$. The crude reaction was concentrated, suspended in $\mathrm{H}_{2} \mathrm{O}$ and washed with AcOEt. The aqueous layer was acidified to $\mathrm{pH} 2$ with $\mathrm{HCl} 3 \mathrm{~N}$ and extracted with AcOEt. The organic layer was dried $\left(\mathrm{MgSO}_{4}\right)$, filtered and evaporated to dryness to give $\mathbf{8}$ as a 50 white solid $(3.40 \mathrm{~g}, 90 \%), \mathrm{mp} 239.3-240.3{ }^{\circ} \mathrm{C}$ (dec). (Found: C, 45.75; H, 4.16; N, 4.72; S, 10.16. $\mathrm{C}_{12} \mathrm{H}_{13} \mathrm{NO}_{7} \mathrm{~S}$ requires $\mathrm{C}$, $45.71 ; \mathrm{H}, 4.16 ; \mathrm{N}, 4.44 ; \mathrm{S}, 10.17 \%) ; v_{\max }(\mathrm{KBr}) / \mathrm{cm}^{-1} 3445$, $1732 ; \delta_{\mathrm{H}}\left(\mathrm{DMSO}-d_{6}\right) 1.96-2.09\left(4 \mathrm{H}, \mathrm{m}, 2 \mathrm{CH}_{2}\right), 3.14-3.23(2 \mathrm{H}$, $\left.\mathrm{m}, \mathrm{CH}_{2} \mathrm{O}\right), 3.92-3.97\left(2 \mathrm{H}, \mathrm{m}, \mathrm{CH}_{2} \mathrm{O}\right), 8.07(2 \mathrm{H}, \mathrm{d}, J 9.1, \mathrm{ArH})$, ${ }_{55} 8.46\left(2 \mathrm{H}, \mathrm{d}, J\right.$ 9.1, ArH); $\delta_{\mathrm{C}}\left(\mathrm{DMSO}-d_{6}\right) 27.9,64.1,71.5$, $124.3,132.1,140.2,151.1,167.5 ;$ MS (ESI): $\mathrm{m} / \mathrm{z} 338.03$ $[\mathrm{M}+\mathrm{Na}]^{+}$.

4-[(4-aminophenyl)sulfonyl]tetrahydro-2H-pyran-4- carboxylic acid (9). A solution of $8(3.94 \mathrm{~g}, 12.50 \mathrm{mmol})$ in ${ }_{60} \mathrm{EtOH}\left(150 \mathrm{~cm}^{3}\right)$ and $\mathrm{H}_{2} \mathrm{O}\left(50 \mathrm{~cm}^{3}\right)$ and $10 \% \mathrm{Pd} / \mathrm{C}(250 \mathrm{mg})$ were introduced into a Parr shaker apparatus, and maintained under a hydrogen pressure of 60 p.s.i for $5 \mathrm{~h}$ at room temperature. Palladium was filtered off and the solvent was removed to obtain 9 as a white solid (3.40 g, 95\%), mp 227.6${ }_{65} 228.8{ }^{\circ} \mathrm{C}$. (Found: C, 50.36; H, 5.25; N, 5.05; S, 11.11. $\mathrm{C}_{12} \mathrm{H}_{15} \mathrm{NO}_{5} \mathrm{~S}$ requires $\mathrm{C}, 50.52 ; \mathrm{H}, 5.30 ; \mathrm{N}, 4.91 ; \mathrm{S}, 11.24 \%$ ); $v_{\max }(\mathrm{KBr}) / \mathrm{cm}^{-1} 3444,3363,3298,1735 ; \delta_{\mathrm{H}}\left(\mathrm{DMSO}-d_{6}\right) 1.82$ $(2 \mathrm{H}, \mathrm{td}, J 12.8$ and $4.9,2 \mathrm{CH} H), 2.04(2 \mathrm{H}, J 12.8,2 \mathrm{CH} H)$, $3.15(2 \mathrm{H}, \mathrm{t}, J 11.6,2 \mathrm{OCH} H), 3.87(2 \mathrm{H}, \mathrm{dd}, J 11.6$ and $3.7 \mathrm{~Hz}$, $702 \mathrm{OCH} H), 6.25\left(2 \mathrm{H}, \mathrm{NH}_{2}\right), 6.61(2 \mathrm{H}, \mathrm{d}, J$ 8.6, $\mathrm{ArH}), 8.46(2 \mathrm{H}$, $\mathrm{d}, J$ 8.6, ArH); $\delta_{\mathrm{C}}\left(\mathrm{DMSO}-d_{6}\right) 28.4,64.3,70.4,112.4,118.7$, 131.9, 154.3, 168.1; MS (ESI): $m / z 308.06[\mathrm{M}+\mathrm{Na}]^{+}$.

4-[(4-Azidophenyl)sulfonyl]tetrahydro-2H-pyran-4-

carboxylic acid (10). Compound 9 (1.99 g, $6.98 \mathrm{mmol})$ was 75 dissolved in anhydrous $\mathrm{CH}_{3} \mathrm{CN}\left(50 \mathrm{~cm}^{3}\right)$ under argon and cooled to $0{ }^{\circ} \mathrm{C}$ in an ice bath. To this solution was added $t$ BuONO (1.24 $\left.\mathrm{cm}^{3}, 10.47 \mathrm{mmol}\right)$, followed by $\mathrm{TMSN}_{3}(1.10$ $\left.\mathrm{cm}^{3}, 8.38 \mathrm{mmol}\right)$ dropwise. The reaction mixture was stirred at $0{ }^{\circ} \mathrm{C}$ for $30 \mathrm{~min}$, and at room temperature for $3 \mathrm{~h}$. Then, it was 80 evaporated to dryness, and the residue was purified by column chromatography on silica gel (DCM/MeOH 97.5:2.5) to afford $10(2.04 \mathrm{~g}, 94 \%)$ as a yellowish solid, mp 191.4-192.4 ${ }^{\circ} \mathrm{C}$ (dec). (Found: C, 46.47; H, 4.24; N, 13.44; S, 10.28. $\mathrm{C}_{12} \mathrm{H}_{13} \mathrm{~N}_{3} \mathrm{O}_{5} \mathrm{~S}$ requires $\mathrm{C}, 46.30 ; \mathrm{H}, 4.21 ; \mathrm{N}, 13.50 ; \mathrm{S}$, $\left.{ }_{85} 10.30 \%\right) ; v_{\max }(\mathrm{KBr}) / \mathrm{cm}^{-1} 3443,2124,2099,1735 ; \delta_{\mathrm{H}}$ (DMSO- $\left.d_{6}\right)$ 1.90-2.07 (4H, m, 2CH $), 3.16(2 \mathrm{H}, \mathrm{t}, J 12.2 \mathrm{~Hz}$, $2 \mathrm{OCH} H), 3.93(2 \mathrm{H}, \mathrm{dd}, J 12.2$ and 3.7, 2OCH $H), 7.37(2 \mathrm{H}, \mathrm{d}$, $J$ 8.6, $\mathrm{ArH}), 7.77\left(2 \mathrm{H}, \mathrm{d}, J\right.$ 8.6, ArH); $\delta_{\mathrm{C}}\left(\mathrm{DMSO}-d_{6}\right) 28.0$, $64.2,70.9,119.7,130.5,132.1,146.1,167.7$; MS (ESI): $\mathrm{m} / \mathrm{z}$ $90333.98[\mathrm{M}+\mathrm{Na}]^{+}$.

4-[(4-Azidophenyl)sulfonyl]-N-(tetrahydro-2H-pyran-2yloxy)tetrahydro-2H-pyran-4-carboxamide (11). To a solution of $10(1.65 \mathrm{~g}, 5.30 \mathrm{mmol})$ in DMF $\left(20 \mathrm{~cm}^{3}\right)$ were added HOBT (859 mg, $6.36 \mathrm{mmol})$, NMM $\left(1.75 \mathrm{~cm}^{3}, 15,90\right.$ $95 \mathrm{mmol})$, O-tetrahydro-2H-pyran-2-yl-hydroxylamine (1.24 g, $10.60 \mathrm{mmol})$ and EDCI $(1.42 \mathrm{~g}, 7.42 \mathrm{mmol})$. The reaction mixture was stirred overnight at room temperature and then diluted with AcOEt $\left(60 \mathrm{~cm}^{3}\right)$ and washed successively with a saturated aqueous solution of $\mathrm{NH}_{4} \mathrm{Cl}$ and brine. The organic 100 layer was dried $\left(\mathrm{MgSO}_{4}\right)$, evaporated to dryness and the solid obtained was recrystallized from $\mathrm{EtOH}$ and water to give $\mathbf{1 1}$ as an orange solid $(1.97 \mathrm{~g}, 91 \%), \mathrm{mp} 194.2-195.8^{\circ} \mathrm{C}$. (Found: $\mathrm{C}, 49.83 ; \mathrm{H}, 5.39 ; \mathrm{N}, 13.58 ; \mathrm{S}, 7.82 . \mathrm{C}_{17} \mathrm{H}_{22} \mathrm{~N}_{4} \mathrm{O}_{6} \mathrm{~S}$ requires $\mathrm{C}$, 49.75; H, 5.40; N, 13.65; S, 7.81\%); $v_{\max }(\mathrm{KBr}) / \mathrm{cm}^{-1} 3323$, 1052139,$1693 ; \delta_{\mathrm{H}}\left(\mathrm{CDCl}_{3}\right) 1.61-1.91\left(6 \mathrm{H}, \mathrm{m}, 3 \mathrm{CH}_{2}\right), 2.08(2 \mathrm{H}, \mathrm{d}$, $\left.\mathrm{CH}_{2}\right) 2.28\left(2 \mathrm{H}\right.$, td $J 13.2$ and $\left.4.9, \mathrm{CH}_{2}\right), 3.46-3.54(2 \mathrm{H}$, "t", $\left.\mathrm{CH}_{2} \mathrm{O}\right) 3.70-3.75\left(1 \mathrm{H}, \mathrm{m}, 1 / 2 \mathrm{CH}_{2} \mathrm{O}\right), 3.97-4.05(3 \mathrm{H}, \mathrm{m}, 3 / 2$ $\left.\mathrm{CH}_{2} \mathrm{O}\right), 5.01(1 \mathrm{H}$, br s, $\mathrm{CH}), 7.37(2 \mathrm{H}, \mathrm{d}, J 8.8, \mathrm{ArH}), 7.85$ $(2 \mathrm{H}, \mathrm{d}, J$ 8.8, $\mathrm{ArH}), 9.42(1 \mathrm{H}, \mathrm{s}, \mathrm{NH}) ; \delta_{\mathrm{C}}\left(\mathrm{CDCl}_{3}\right) 18.2,24.9$, $11027.7,28.3,28.5,62.3,64.2,64.3,70.0,101.9,119.6,129.6$, 132.0, 147.0, 163.9; MS (ESI): $m / z 433.12[\mathrm{M}+\mathrm{Na}]^{+}$.

4-[(4-Azidophenyl)sulfonyl]-N-hydroxytetrahydro-2Hpyran-4-carboxamide (12). To a solution of 11 (1.92 g, 4.69 $\mathrm{mmol})$ in dioxane $\left(10 \mathrm{~cm}^{3}\right)$ was added $4 \mathrm{~N} \mathrm{HCl}$ in dioxane $115\left(5.86 \mathrm{~cm}^{3}, 23.43 \mathrm{mmol}\right)$ followed by $\mathrm{MeOH}\left(10 \mathrm{~cm}^{3}\right)$. After strirring at room temperature for $2 \mathrm{~h}$, the reaction mixture was 
concentrated under vacuum and the obtained solid was recrystallized from EtOH and water to give 12 (1.36 g, 89\%) as an orange solid, $\mathrm{mp} 197.2-198.1{ }^{\circ} \mathrm{C}$ (dec). (Found: C, 44.37; H, 4.47; N, 16.80; S, 9.70. $\mathrm{C}_{12} \mathrm{H}_{14} \mathrm{~N}_{4} \mathrm{O}_{5} \mathrm{~S}$ requires $\mathrm{C}$, $\left.{ }_{5} 44.17 ; \mathrm{H}, 4.32 ; \mathrm{N}, 17.17 ; \mathrm{S}, 9.83 \%\right) ; v_{\max }(\mathrm{KBr}) / \mathrm{cm}^{-1} 3349$, $3194,2142,1681 ; \delta_{\mathrm{H}}\left(\mathrm{DMSO}-d_{6}\right) 1.90(2 \mathrm{H}, \mathrm{td}, J 12.8$ and 4.3 , $2 \mathrm{CH} H), 2.20(2 \mathrm{H}, \mathrm{d}, J 12.8 \mathrm{H}, 2 \mathrm{CH} H), 3.14(2 \mathrm{H}, \mathrm{t}, J 11.6$, $2 \mathrm{OCH} H), 3.88(2 \mathrm{H}, \mathrm{dd}, J 11.6$ and $3.7,2 \mathrm{OCH} H), 7.35(2 \mathrm{H}, \mathrm{d}$, $J$ 8.6, ArH), 7.77 (2H, d, $J$ 8.6, ArH), $9.23(1 \mathrm{H}, \mathrm{s}, \mathrm{NH}), 11.03$

${ }_{10}(1 \mathrm{H}, \mathrm{s}, \mathrm{OH}) ; \delta_{\mathrm{C}}\left(\mathrm{DMSO}-d_{6}\right) .27 .4,63.9,69.3,119.6,130.3$, 132.1, 145.9, 160.6; MS (ESI): $m / z 349.06[\mathrm{M}+\mathrm{Na}]^{+}$.

General procedure for the preparation of triazoles. To a suspension, of azide 12 (1 equiv) and the corresponding alkyne (1.2 equiv) in $t$ - $\mathrm{BuOH} / \mathrm{H}_{2} \mathrm{O}(1: 1,5)$ was added sodium 15 ascorbate (2 equiv of freshly prepared $1 \mathrm{M}$ solution in water) and copper(II) sulfate pentahydrate $(0.5$ equiv of a $0.25 \mathrm{M}$ solution in water) under argon. The mixture was stirred vigorously overnight, and then diluted with water $\left(20 \mathrm{~cm}^{3}\right)$ and ice. The precipitate formed was collected by filtration and 20 washed with cold water and hexane. The solid was solved in a DCM:MeOH: $\mathrm{NH}_{3}$ (aqueous) 6:3:1 mixture, filtered through silica gel and the filtrate was concentrated under vacuum.

$\mathrm{N}$-Hydroxy-4-(\{[4-(4-phenoxyphenyl)-1H-1,2,3-triazole-1yl]phenyl\}sulfonyl)tetrahydro-2H-pyran-4-carboxamide

25 (13). From 12 (57.7 mg, $0.18 \mathrm{mmol})$, 1-ethynyl-4phenoxybencene $(41.2 \mathrm{mg}, 0.21 \mathrm{mmol})$, sodium ascorbate (354 $\mu \mathrm{L}, 0.35 \mathrm{mmol})$ and copper(II) sulfate pentahydrate (354 $\mu \mathrm{L}, 0.09 \mathrm{mmol}) 13(60 \mathrm{mg}, 65 \%)$ was produced as a white solid, mp 216.4-217.9 ${ }^{\circ} \mathrm{C}$ (dec). (Found: C, 59.58; H, 4.72; N, $3010.35 ; \mathrm{S}, 5.91 . \mathrm{C}_{26} \mathrm{H}_{24} \mathrm{~N}_{4} \mathrm{O}_{6} \mathrm{~S}$ requires $\mathrm{C}, 59.99 ; \mathrm{H}, 4.65 ; \mathrm{N}$, $10.76 ; \mathrm{S}, 6.16 \%) ; v_{\max }(\mathrm{KBr}) / \mathrm{cm}^{-1} 3230,1669 ; \delta_{\mathrm{H}}\left(\mathrm{DMSO}-d_{6}\right)$ $1.99(2 \mathrm{H}, \mathrm{td}, J 12.8$ and $4.9,2 \mathrm{CH}), 2.26(2 \mathrm{H}, \mathrm{d}, J 12.8$, $2 \mathrm{CH} H), 3.17(2 \mathrm{H}, \mathrm{t}, J 11.6,2 \mathrm{OCH} H), 3.91(2 \mathrm{H}, \mathrm{dd}, J 11.6$ and 3.7, 2OCHH), 7.08-7.22 (5H, m, ArH), $7.44(2 \mathrm{H}, \mathrm{t}, \mathrm{ArH})$, 35 7.96-8.04 (4H, m, ArH), 8.24 (2H, d, J 8.6, ArH), 9.29 (1H, br s, NH), $9.48\left(1 \mathrm{H}, \mathrm{s}\right.$, Triazole-H) $11.10(1 \mathrm{H}$, br s, OH $) . \delta_{\mathrm{C}}$ $\left(\mathrm{DMSO}-d_{6 .}\right)$ 27.4, 64.0, 69.7, 119.2, 119.3, 119.7, 120.0, $124.0,125.1,127.4,130.3,132.4,134.0,140.6,147.5,156.4$, 157.2, 160.5; MS (ESI): $m / z 521.18[\mathrm{M}+\mathrm{H}]^{+}$.

${ }_{40} \mathrm{~N}$-Hydroxy-4-(\{4-[4-(4-methylphenyl)-1H-1,2,3-triazole-1yl]phenyl\}sulfonyl)tetrahydro-2H-pyran-4-carboxamide

(14). From 12 (66.3 mg, $0.20 \mathrm{mmol})$, 1-ethynyl-4methylbenzene $(28.3 \mathrm{mg}, 0.24 \mathrm{mmol})$, sodium ascorbate (406 $\mu \mathrm{L}, 0.41 \mathrm{mmol})$ and copper(II) sulfate pentahydrate $(406 \mu \mathrm{L}$, 45 $0.10 \mathrm{mmol}) 14$ (57 mg, 63\%) was produced as a yellow solid, m.p. $208.1-209.4^{\circ} \mathrm{C}(\mathrm{dec})$.

$N$-Hydroxy-4-(\{4-[4-(4-pentylphenyl)-1H-1,2,3-triazole-1yl]phenyl\}sulfonyl)tetrahydro-2H-pyran-4-carboxamide

(15). From 12 (45.3 mg, 0.14 mmol), 1-ethynyl-4so pentylbenzene $(28.7 \mathrm{mg}, 0.17 \mathrm{mmol})$, sodium ascorbate $(278$ $\mu \mathrm{L}, 0.28 \mathrm{mmol})$ and copper(II) sulfate pentahydrate $(278 \mu \mathrm{L}$, $0.07 \mathrm{mmol}) 15(45 \mathrm{mg}, 65 \%)$ was produced as a brown solid mp 198.0-199. $7^{\circ} \mathrm{C}(\mathrm{dec})$.

$\mathrm{N}$-Hydroxy-4-(\{4-[4-(4-pentylbenzyl)-1H-1,2,3-triazole-1${ }_{55}$ yl]phenyl\}sulfonyl)tetrahydro-2H-pyran-4-carboxamide (16). From 12 (80 mg, $0.25 \mathrm{mmol}), 3$ (54.8 mg, $0.29 \mathrm{mmol})$ sodium ascorbate $(490 \mu \mathrm{L}, 0.49 \mathrm{mmol})$ and copper(II) sulfate pentahydrate $(490 \mu \mathrm{L}, 0.12 \mathrm{mmol}), 16$ (60 $\mathrm{mg}, 48 \%)$ was produced as a white solid, mp $167.8-168.9^{\circ} \mathrm{C}$.

${ }_{60} \mathrm{~N}$-Hydroxy-4-\{[4-(4-phenyl-1H-1,2,3-triazole-1yl)phenyl]sulfonyl\}tetrahydro-2H-pyran-4-carboxamide (17). From 12 (71.6 mg, $0.22 \mathrm{mmol})$, phenylacetylene (26.9 $\mathrm{mg}, 0.26 \mathrm{mmol})$, sodium ascorbate $(438 \mu \mathrm{L}, 0.44 \mathrm{mmol})$ and copper(II) sulfate pentahydrate $(438 \mu \mathrm{L}, 0.11 \mathrm{mmol}), 17$ (26.7 ${ }_{65} \mathrm{mg}, 28 \%$ ) was produced as a white solid $\mathrm{mp} 228.9-230.5^{\circ} \mathrm{C}$ (dec).

$N$-Hydroxy-4-\{[4-(4-biphenyl-4-yl-1H-1,2,3-triazole-1yl)phenyl]sulfonyl\}tetrahydro-2H-pyran-4-carboxamide (18). From 12 (60 mg, $0.18 \mathrm{mmol})$, 4-ethynylbiphenyl (39.3 $70 \mathrm{mg}, 0.22 \mathrm{mmol})$ sodium ascorbate $(368 \mu \mathrm{L}, 0.37 \mathrm{mmol})$ and copper(II) sulfate pentahydrate $(368 \mu \mathrm{L}, 0.09 \mathrm{mmol}) \mathbf{1 8}(56$ $\mathrm{mg}, 60 \%$ ) was produced as a yellow solid, $\mathrm{mp} 227.7-229.0^{\circ} \mathrm{C}$ (dec).

$N$-hydroxy-4-(\{4-[4-(4-methoxyphenyl)-1H-1,2,3-triazole75 1-yl]phenyl $\}$ sulfonyl)tetrahydro-2H-pyran-4-carboxamide (19). From 12 (100 mg, $0.31 \mathrm{mmol})$, 4-ethynylanisol (48.6 $\mathrm{mg}, 0.37 \mathrm{mmol})$ sodium ascorbate $(612 \mu \mathrm{L}, 0.61 \mathrm{mmol})$ and copper(II) sulfate pentahydrate $(612 \mu \mathrm{L}, 0.15 \mathrm{mmol}), 19$ (86 $\mathrm{mg}, 61 \%$ ) was produced as a yellow solid, $\mathrm{mp} 217.1-218.3{ }^{\circ} \mathrm{C}$ $80(\mathrm{dec})$.

4-\{[4-(4-Butyl-1H-1,2,3-triazole-1-yl)phenyl]sulfonyl\}-Nhydroxytetrahydro-2H-pyran-4-carboxamide (20). From 12 (82.9 $\mathrm{mg}, 0.25 \mathrm{mmol})$, 1-hexine $(54.8 \mathrm{mg}, 0.30 \mathrm{mmol})$, sodium ascorbate $(508 \mu \mathrm{L}, 0.51 \mathrm{mmol})$ and copper(II) sulfate ${ }_{85}$ pentahydrate $(508 \mu \mathrm{L}, 0.13 \mathrm{mmol}) 20(67 \mathrm{mg}, 65 \%)$ was produced as a white solid $\mathrm{mp} 164.5-166.0^{\circ} \mathrm{C}(\mathrm{dec})$.

$N$-hydroxy-4-[(4- $\{4-$

[((phenylsulfonyl)carbamoylamino)methyl]-1H-1,2,3triazole-1-yl\}phenyl)sulfonyl]-tetrahydro-2 $\mathrm{H}$-pyran-490 carboxamide (21). From 12 (105.4 mg, $0.32 \mathrm{mmol}), 2$ (92.3 $\mathrm{mg}, 0.39 \mathrm{mmol})$, sodium ascorbate $(646 \mu \mathrm{L}, 0.65 \mathrm{mmol})$ and copper(II) sulfate pentahydrate (646 $\mu \mathrm{L}, 0.16 \mathrm{mmol}), 21$ (98 $\mathrm{mg}, 79 \%$ ) was produced as a white solid m.p. $185.0^{\circ} \mathrm{C}$ (dec). $\mathrm{N}$-Hydroxy-4-(\{[4-(4-phenoxybenzyl)-1H-1,2,3-triazole-1-

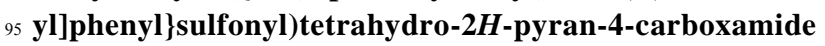
(22). From 12 (80 mg, $0.25 \mathrm{mmol}), 4$ (61.3 mg, $0.29 \mathrm{mmol})$, sodium ascorbate $(490 \mu \mathrm{L}, 0.49 \mathrm{mmol})$ and copper(II) sulfate pentahydrate $(490 \mu \mathrm{L}, 0.12 \mathrm{mmol}), 22$ (36 mg, 27\%) was produced as a white solid mp $138.0-139.3{ }^{\circ} \mathrm{C}(\mathrm{dec})$.

\section{Molecular Modeling. Ligand processing}

All ligands (together with compound i52) were first build using CORINA, ${ }^{39}$ in its neutral protonation state and extended conformation. Assignment of the atom types and charge calculations were performed with Sybyl 7.3 (Gasteiger105 Marsili charges). ${ }^{40}$ A minimization for each compound was first carried out using the program Macromodel. ${ }^{41}$ Water was set as solvent, and charges selected from the mol2 file created with Sybyl. The program was set to explore through 500 steps. The force field selected was AMBER. A conformational 110 analysis was then performed to all compounds to be docked by use of the program Macromodel ${ }^{41}$ and the Monte Carlo methodology ${ }^{42}$ that allows the random variation of the selected torsional angles. The parameters given to Macromodel were set to default with some changes: the force 115 field selected was AMBER, as explained before, and a 
distance-dependent dielectric constant of $1.0 \mathrm{~GB} / \mathrm{SA}$ solvation model $^{43}$ was selected. The program was set to explore through 500 steps modifying three torsional angles each step. The limit of acceptance was set to $50 \mathrm{kj} / \mathrm{mol}$ above the instant 5 minimum found. The minimization method selected was conjugated gradient. ${ }^{44}$ The convergence RMS to evaluate if two conformers are similar was set to a limit of $2 \AA$. The criteria of minimization convergence was set to 0.05 $(\mathrm{kj} / \mathrm{mol}) / \AA$, that is, if a minimization step of a structure is not 10 able to improve in more than $0.05(\mathrm{kj} / \mathrm{mol}) / \AA$ the predecessor structure, the energetic minimum has been achieved.

Superimposition. All the conformers resulting from the conformational search were then superimposed to the ligand i52 is present in PDB 1 hov (model 1). This ligand was 15 previously submitted to the same conformational search analysis and followed the same superimposition procedure in order to validate the methodology. The criteria selected for the superimposition was the maximum number of atoms fitted using the CSR program, ${ }^{45}$ and the minimum value of the Root 20 Mean Square Deviation (RMSD). Only the conformers with the higher number of fitted atoms were selected for the docking studies.

\section{Docking Studies with AutoDock3 ${ }^{46}$}

MMP2 catalytic domain from PDB 1hov (model 1) was 25 employed as macromolecule. For the zinc ion, the parameter set reported by Stote et al. ${ }^{47}$ was used, which means $\mathrm{r}=1.1 \AA$, $\varepsilon=0.25 \mathrm{kcal} / \mathrm{mol}$ and a formal charge of $+2 \mathrm{e}$. Affinity grid files were generated using the auxiliary program AutoGrid. ${ }^{48}$ The grid size was set to $128 \times 60 \times 60$ points with a grid 30 spacing of $0.375 \AA$ containing the S1', S2' and S1 subsites, together with the catalytic zinc. The Lamarckian Genetic Algorithm (LGA) was used as the search engine. The original Lennard-Jonnes and hydrogen-bonding potentials provided by the program were used. Step sizes of $2 \AA$ for translation and ${ }_{35} 60^{\circ}$ for rotation were chosen. A maximum number of energy evaluations was set to 250.000 . For each of the 100 independent runs, a maximum number of 27.000 LGA operations were generated on a single population of 100 individuals. Operator weights for crossover, mutation, and 40 elitism were set to $0.80,0.20$ and 1 , respectively. The parameters for the docking using LGA were identical for all docking jobs. After docking, the 100 solutions were clustered in groups with root mean square (rms) deviations less than 1.0 $\AA$. The clusters were ranked by the lowest energy 45 representative of each cluster.

The compounds were studied with no restraints between the ZBG and the zinc atom. Other variables were set to default values using AutoDock Tools (ADT). ${ }^{46}$

We have followed several docking protocols, which include: so random docking, in which all possible torsionals of each compound were activated, and the starting point of each conformation was randomly selected by the program; superimposed docking, in which the nitrogen atom from the hydroxamate group was superimposed with the same nitrogen 55 atom of compound i52, and selected as starting point of the docking study (in this case all possible torsionals were activated); rigid random docking, in which the starting point of each conformation was randomly selected by the program, but all torsionals were inactivated, so that the docked ${ }_{60}$ conformation was the one obtained from the superimposition with ligand i52.

\section{Docking Studies with GLIDE ${ }^{49-51}$}

GLIDE program was used to develop docking studies for all compounds. First, structure of MMP2 catalytic domain 65 obtained from PDB 1 hov (model 1) was optimized and minimized using the Protein preparation wizard application integrated in Glide's package. Then, interaction maps of the protein binging site were created using the Receptor grid generation application, also included in Glide's package, and 70 selecting ligand i52 as the centre of the grid box. All compounds were prepared using the Ligprep application. OPLS-2005 force field was selected for both protein and ligands preparation. Docking studies were performed randomly. For each docking study the program was set to 75 explore through 10.000 steps and a maximum number of 10 poses per ligand. The selected docking method was XP (Extra-Precision). ${ }^{52}$

Data analysis. All docking results were manually analyzed. The cut off value for coordinating distances, between the 80 catalytic $\mathrm{Zn}^{2+}$ ion and the oxygen atoms (or atom) from the hydroxamic group of the inhibitor, was set to $2.53 \AA$, as this is the maximum reported distance between a coordinating atom and the MMP zinc ion. ${ }^{53}$ For each potential docked solution, angles were measured to assure they are the optimal ones for 85 the coordination geometries and the conformers were classified into three different categories depending on their coordination geometry with the catalytic zinc ion: a trigonal bipyramidal coordination, a square-based pyramid coordination and no coordinating pattern, using the mean 90 atom distance and angles displacement published by Alberts et al. (Figure 8$).^{53}$
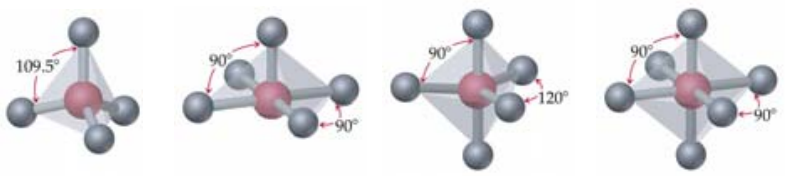

$$
\begin{array}{lccc}
\begin{array}{l}
\text { Tetrahedrical } \\
\text { coordination }
\end{array} & \begin{array}{c}
\text { Square-based } \\
\text { pyramidal }
\end{array} & \begin{array}{c}
\text { Trigonal } \\
\text { bipyramidal }
\end{array} & \begin{array}{c}
\text { Octahedrical } \\
\text { coordination }
\end{array}
\end{array}
$$

Fig. 8 Different geometries for the coordination of the $\mathrm{Zn}^{2+}$ ion found in the bibliography for zinc-dependent proteases. MMPIs are found to coordinate by square-based pyramidal or trigonal bipyramidal 95 geometry. ${ }^{53,54}$ Zinc ion is represented in colour red and the coordinating atoms are represented in grey (coordinating atoms in MMP are three histidines and one or two atoms of the ligand).

Energies were scrutinized, selecting only those docking 100 solutions with a favourable binding energy $\left(\mathrm{E}_{\text {docked }}<0\right.$ $\mathrm{Kcal} / \mathrm{mol}$ ). All docking results not matching all these specific characteristics (distances, angles and docked energy) were 
rejected.

\section{Molecular Dynamics Simulations.}

Charge calculation. Geometries of $\mathbf{1 8}$ and $\mathbf{1 9}$ were optimized at the B3LYP/3-21G* level of theory and basis set, followed 5 by a B3LYP/6-31G* single-point energy calculation to determine the electrostatic potential around the molecule, which was subsequently used in the two-stage RESP fitting procedure in order to obtain point charges. ${ }^{55}$ All $a b$ initio calculations were carried out using Gaussian 03 suite of 10 programs. $^{56}$

Molecular Dynamics Simulations. The following parameters were assigned to zinc atom: van der Waals parameters of $r=$ $3.1 \AA$, and $\varepsilon=1 \mathrm{E}^{-6} \mathrm{kcal} / \mathrm{mol}$, charge of zero, and a mass of 50.38 u.m.a. To each of the five dummy atoms covalently 15 bonded to zinc, the following parameters were assigned: charge of +0.4 , van der Waals parameters $r$ and $\varepsilon$ of zero, and mass of 0.1 u.m.a. Protein-ligand system was first minimized in vacuum for 1000 steps of steepest descent followed by 4000 steps of conjugate gradient using AMBER 9 20 program. ${ }^{57} \mathrm{All} \mathrm{C} \alpha$ atoms were restrained to their initial coordinates. Distance and angle restrictions were applied on the catalytic zinc, the dummy atoms and the ZBG atoms. This procedure allowed readjustment of covalent bonds and van der Waals contacts without changing the overall conformation of 25 the protein. The resulting minimized complex was solvated by a box of TIP3P waters which extended at least $8 \AA$ away from any given protein atom ( $\sim 9500$ TIP3P water molecules). Periodic boundary conditions were applied and electrostatic interactions were represented using the smooth Particle Mesh ${ }_{30}$ Ewald (PME) method $^{58}$ with a grid spacing of $\sim 1 \AA$. First, all hydrogen atoms were minimized for 1000 steps of steepest descent. Next, the position of water molecules was relaxed for 2000 steps of steepest descent followed by 3000 steps of conjugate gradient. Finally, the whole system, including the 35 solute, was energy minimized for 2000 steps of steepest descent plus 3000 steps of conjugate gradients. At this point, the complex was kept frozen and started the thermalization of the solvent by running three 30 -ps MD simulations to increase the temperature up to $300 \mathrm{~K}$. Positional constraints were only 40 applied on the ZBG (His120, His124, His130, and the two coordinating oxygen atoms of $\mathbf{1 8}$ and 19) during 500 ps. During the next 500 ps restrains were gradually lowered, followed by 3-ns unrestrained MD simulation (RMSD, Supporting Information).

\section{Zymography}

Human blood serum from a healthy volunteer was used as the source of gelatinases. ${ }^{12}$ Equal amounts of serum $(1.5 \mu \mathrm{l})$ were loaded on each well of a $10 \%$ gelatin zymogram gel 50 (Invitrogen, Carlsbad, CA,USA). After electrophoresis, the gel was incubated for $30 \mathrm{~min}$ in renaturing buffer and then in developing buffer for another $30 \mathrm{~min}$, both at room temperature. At this point, gels were cut in individual lanes which were incubated in the presence of the inhibitors in ${ }_{55}$ developing buffer overnight at $37^{\circ} \mathrm{C}$. Following several washes, the gel fragments were stained with Simply Blue
(Invitrogen), destained, and scanned with Odyssey (Li-cor, Lincoln, Nebraska, USA). Gelatinolytic activity for each enzyme (MMP2, $72 \mathrm{kDa}$; MMP9, $92 \mathrm{kDa}$ ) was quantified by 60 image analysis (Image-J, NIH, Bethesda, MD, USA) and the $\mathrm{IC}_{50}$ values were calculated with MS Excel-add-in XLfit (IDBS, UL, Vs. 5.0).

\section{MMPs Inhibition Assays}

${ }_{65}$ MMPs activity measurements were performed by using $M M P$ Inhibitor Profiling Kit purchased from Enzo Life Science International, Inc., following the manufacturer's protocol with slight modifications. Proteolytic activity was measured using a thiopeptide substrate (Ac-PLG-[2-mercapto-470 methylpentanoyl]-LG- $-\mathrm{OC}_{2} \mathrm{H}_{5}$ ) where the MMP cleavage site peptide bond has been replaced by a thioester bond. ${ }^{59,60}$ Hydrolysis of this bond by MMP produces a sulfhydryl group that reacts with DTNB to form 2-nitro-5-thiobenzoic acid, which was detected by its absorbance at $414 \mathrm{~nm}$ (microplate 75 photometer Thermo Scientific Multiscan FC). Enzyme reactions were carried out at $37^{\circ} \mathrm{C}$ in a $100 \mu \mathrm{l}$ final volume of solutions, where the catalytic domains of the corresponding MMP were incubated in triplicate with at least six concentrations of inhibitors. The assay buffer contained the 80 following components: $50 \mathrm{mM}$ HEPES, $10 \mathrm{mM} \mathrm{CaCl}_{2}, 0.05 \%$ Brij-35 and $1 \mathrm{mM}$ DTNB at $\mathrm{pH}$ 7.5. After addition of substrate, the increase of absorbance was recorded in $1 \mathrm{~min}$ time intervals for $20 \mathrm{~min}$. Data were plotted as OD versus time for each sample, in order to obtain the reaction velocity ${ }_{85}(\mathrm{~V})$ in $\mathrm{OD} / \mathrm{min}$. The percentage of residual activity for each compound was calculated using the following formula: \% of remaining activity $=(\mathrm{V}$ in the presence of inhibitor/Vcontrol)x100. An inhibitor, NNGH, was included as a prototypic control inhibitor. ${ }^{61}$ The concentration of 90 compound that provided $50 \%$ inhibition of enzymatic activity $\left(\mathrm{IC}_{50}\right)$ was determined by semilogarithmic dose-response plots (Graph Pad Prism 5.0).

\section{NMR experiments}

95 All spectra were recorded at $300 \mathrm{~K}$ either with a Bruker Ultrashield Plus Avance II $600 \mathrm{MHz}$ or an Avance III 500 $\mathrm{MHz}$ spectrometer. The $600 \mathrm{MHz}$ spectrometer is equipped with a $5 \mathrm{~mm}$ cryogenically cooled TCI probe, the $500 \mathrm{MHz}$ with a broadband room-temperature TBI probe. A typical 100 NMR sample contained a concentration of 1-5 $\mu \mathrm{M}$ of MMP2 (expression and purification details of this MMP2 construct will be published elsewhere) and $20-100 \mu \mathrm{M}$ of ligand, in an approximate ratio protein:ligand of 1:20, optimal for the water-LOGSY experiments. The sample buffer was $10 \mathrm{mM}$ 105 deuterated-Tris/ $\mathrm{HCl} \mathrm{pH} 7.4$ with $50 \mathrm{mM} \mathrm{NaCl}, 0.02 \% \mathrm{NaN}_{3}$, $100 \mu \mathrm{M} \mathrm{CaCl} l_{2}$ and $100 \mu \mathrm{M} \mathrm{ZnCl}$. The concentration of ligand for the Saturation Transfer Difference (STD) experiments kept a ratio protein:ligand 1:100. $200 \mu \mathrm{M}$ of BiPS was added for the competition experiments. For each 110 sample, a $1 \mathrm{D}{ }^{1} \mathrm{H}$ reference, a water-LOGSY and a STD experiment were recorded. $8 \mathrm{~K}$ points were used for a sweep width of $9,600 \mathrm{~Hz}$ and a total of $1 \mathrm{~K}$ and 512 scans were 
accumulated for the water-LOGSY and STD experiments, respectively. In the water-LOGSY experiments, the large bulk water magnetization is partially transferred via the proteinligand complex to the free ligand in a selective manner. A non 5 interacting compound results in negative resonances, whereas protein-ligand interactions are characterized by positive signals or by a reduction in the negative signals obtained in the absence of the protein. In the STD experiment, a positive interaction is recognized by the presence of positive signals, a 10 negative interaction yielding no signals. BiPS was purchased from VWR (Barcelona, Spain).

\section{Acknowledgement}

This work was supported by the Spanish Ministry of Science and Innovation (SAF2005-02608, SAF2008-00945, SAF200815 01845, and SAF2009-13240). R. J. C. thanks Spanish Ministry of Science for a Ramón y Cajal contract. Grants to P. S. from the Spanish Ministry of Education (FPU program), and to J. M. Z. from Fundación Universitaria San Pablo CEU are also acknowledged. We thank EADS-CASA for a fellowship to K. ${ }_{20} \mathrm{~F}$. This work was awarded a "Premio del Colegio Oficial de Farmacéuticos de Madrid", given by the Real Academia Nacional de Farmacia (Spain, 2010).

\section{Notes and references}

$25{ }^{a}$ Departamento de Química, Facultad de Farmacia, Universidad San Pablo CEU, Urbanización Montepríncipe, 28668 Boadilla del Monte, Madrid, Spain. Phone: (+34)913724724, Fax: (+34)913510496 E-mail: aramgon@ceu.es; bpaster@ceu.es

${ }^{b}$ Center for Biomedical Research of La Rioja (CIBIR) C/ Piqueras 98, 3026006 Logroño, Spain.

${ }^{c}$ Department of Molecular Biology, Faculty of Mathematics and Natural Sciences, The John Paul II Catholic University of Lublin, 20-718 Lublin, Poland.

${ }^{d}$ Structural Biology Laboratory, Medicinal Chemistry Department, 35 Centro de Investigación Príncipe Felipe, Avda. Autopista del Saler, 16,46012 Valencia, Spain

$\dagger$ Electronic Supplementary Information (ESI) available: IR, ${ }^{1} \mathrm{H}$ and ${ }^{13} \mathrm{C}$ 40 NMR, MS (ESI) and microanalysis data of compounds 14-22. Evolution of the root-mean-square deviations (RMDS) and some distances monitored for the MD simulations. See DOI: 10.1039/b000000x/

+ Abbreviations: DTNB, 5,5'-dithiobis-(2-nitrobenzoic acid); HEPES, 4(2-hydroxyethyl)-1-piperazineethanesulfonic acid; Brij-35,

45 polyoxyethyleneglycol dodecyl ether; PDB, Protein Data Bank; DCM, dichloromethane ; THP, tetrahydropyrane; THF, tetrahydrofurane; EDC, $N$-(3-dimethylaminopropyl)- $N$ '-ethylcarbodiimidehydrochloride; $\quad$ TFA, trifluoroacetic acid; DMAP, 4-(dimethylamino)pyridine.

50

1. Cawston, T. E., Pharmacol. Ther. 1996, 70, 163-182.

2. Bottomley, K. M.; Johnson, W. H.; Walter, D. S., J. Enzym. Inhib. 1998, 13, 79-101.

55 3. Massova, I.; Kotra, L. P.; Fridman, R.; Mobashery, S., FASEB J. 1998, 12, 1075-1095.

4. Overall, C. M.; Kleifeld, O., Nat. Rev. Cancer 2006, 6, 227-239.

5. Summers, J. B., In Annual Reports in Medicinal Chemistry, Robertson, D.; Plattner, J., Eds. Academic Press: San Diego, 1998; $60 \quad$ Vol. 33, pp 131-149.
6. Bertini, I.; Calderone, V.; Fragai, M.; Giachetti, A.; Loconte, M.; Luchinat, C.; Maletta, M.; Nativi, C.; Yeo, K. J., J. Am. Chem. Soc. 2007, 129, 2466-2475.

7. Nicolotti, O.; Miscioscia, T. F.; Leonetti, F.; Muncipinto, G.; Carotti, 65 A., J. Chem. Inf. Model. 2007, 47, 2439-2448.

8. Skiles, J. W.; Gonnella, N. C.; Jeng, A. Y., Curr. Med. Chem. 2001, 8, 425-474.

9. Engel, C. K.; Pirard, B.; Schimanski, S.; Kirsch, R.; Habermann, J.; Klingler, O.; Schlotte, V.; Weithmann, K. U.; Wendt, K. U., Chem. Biol. 2005, 12, 181-189.

10. Amadasi, A.; Cozzini, P.; Incerti, M.; Duce, E.; Fisicaro, E.; Vicini, P., Bioorg. Med. Chem. 2007, 15, 1420-1429.

11. Tuccinardi, T.; Martinelli, A.; Nuti, E.; Carelli, P.; Balzano, F.; Uccello-Barretta, G.; Murphy, G.; Rossello, A., Bioorg. Med. Chem. 2006, 14, 4260-4276.

12. Becker, D. P.; Barta, T. E.; Bedell, L. J.; Boehm, T. L.; Bond, B. R.; Carroll, J.; Carron, C. P.; DeCrescenzo, G. A.; Easton, A. M.; Freskos, J. N.; Funckes-Shippy, C. L.; Heron, M.; Hockerman, S. L.; Howard, C. P.; Kiefer, J. R.; Li, M. H. M., K. J.; McDonald, J. J.; Mehta, P. P.; Munie, G. H.; Sunyer, Y.; Swearingen, C.; Villamil, C. I.; Welsch, D.; Williams, J. M.; Yu, Y.; Yao, J., J. Med. Chem. 2010, 53, 6653-6680.

13. Martin, M. D.; Matrisian, L. M., Cancer Metastasis Rev. 2007, 26, 717-724.

85 14. Almholt, K.; Juncker-Jensen, A.; Laerum, O. D.; Dano, K.; Johnsen, M.; Lund, L. R.; Romer, J., Mol. Cancer Ther. 2008, 7, 2758-2767.

15. Hu, J.; Van den Steen, P. E.; Sang, Q. X.; Opdenakker, G., Nat. Rev. Drug Discov. 2007, 6, 480-498.

16. Becker, D. P.; Villamil, C. I.; Barta, T. E.; Bedell, L. J.; Boehm, T.

$90 \quad$ L.; DeCrescenzo, G. A.; Freskos, J. N.; Getman, D. P.; Hockerman, S.; Heintz, R.; Howard, S. C.; Li, M. H.; McDonald, J. J.; Carron, C. P.; Funckes-Shippy, C. L.; Mehta, P. P.; Munie, G. E.; Swearingen, C. A., J. Med. Chem. 2005, 48, 6713-6730.

17. Kolodziej, S. A.; Hockerman, S. L.; Boehm, T. L.; Carroll, J. N.; 95 DeCrescenzo, G. A.; McDonald, J. J.; Mischke, D. A.; Munie, G. E.; Fletcher, T. R.; Rico, J. G.; Stehle, N. W.; Swearingen, C.; Becker, D. P., Bioorg. Med. Chem. Lett. 2010, 20, 3557-3560.

18. Kolodziej, S. A.; Hockerman, S. L.; DeCrescenzo, G. A.; McDonald, J. J.; Mischke, D. A.; Munie, G. E.; Fletcher, T. R.; Stehle, N.; Swearingen, C.; Becker, D. P., Bioorg. Med. Chem. Lett. 2010, 20, 3561-3564

19. Manetsch, R.; Krasinski, A.; Radic, Z.; Raushel, J.; Taylor, P.; Sharpless, K. B.; Kolb, H. C., J. Am. Chem. Soc. 2004, 126, 1280912818.

105 20. Lewis, W. G.; Green, L. G.; Grynszpan, F.; Radic, Z.; Carlier, P. R.; Taylor, P.; Finn, M. G.; Sharpless, K. B., Angew. Chem. Int. Ed. Engl. 2002, 41, 1053-1057.

21. Krasinski, A.; Radic, Z.; Manetsch, R.; Raushel, J.; Taylor, P.; Sharpless, K. B.; Kolb, H. C., J. Am. Chem. Soc. 2005, 127, 66866692.

22. Whiting, M.; Muldoon, J.; Lin, Y. C.; Silverman, S. M.; Lindstrom, W.; Olson, A. J.; Kolb, H. C.; Finn, M. G.; Sharpless, K. B.; Elder, J. H.; Fokin, V. V., Angew. Chem. Int. Ed. Engl. 2006, 45, 1435-1439.

23. Mocharla, V. P.; Colasson, B.; Lee, L. V.; Roper, S.; Sharpless, K. 115 B.; Wong, C. H.; Kolb, H. C., Angew. Chem. Int. Ed. Engl. 2005, 44, 116-120.

24. Srinivasan, R.; Uttamchandani, M.; Yao, S. Q., Org. Lett. 2006, 8, 713-716.

25. Ng, S. L.; Yang, P. Y.; Chen, K. Y. T.; Srinivasan, R.; Yao, S. Q., Org. Biomol. Chem. 2008.

26. Wang, J.; Uttamchandani, M.; Li, J. Q.; Hu, M. Y.; Yao, S. Q., Org. Lett. 2006, 8, 3821-3824.

27. Himo, F.; Lovell, T.; Hilgraf, R.; Rostovtsev, V. V.; Noodleman, L.; Sharpless, K. B.; Fokin, V. V., J. Am. Chem. Soc. 2005, 127, 210216.

28. García, M. A., PhD Thesis 2007.

29. Scozzafava, A.; Supuran, C. T., J. Med. Chem. 2000, 43, 1858-1865.

30. Pang, Y. P., J. Mol. Model. 1999, 5, 196-202.

31. Kupai, K.; Szucs, G.; Cseh, S.; Hajdu, I.; Csonka, C.; Csont, T.; Ferdinandy, P., J. Pharmacol. Toxicol. Methods 2010, 61, 205-209. 
32. Tamura, Y.; Watanabe, F.; Nakatani, T.; Yasui, K.; Fuji, M.; Komurasaki, T.; Tsuzuki, H.; Maekawa, R.; Yoshioka, T.; Kawada, K.; Sugita, K.; Ohtani, M., J. Med. Chem. 1998, 41, 640-649.

33. Dragoni, E.; Calderone, V.; Fragai, M.; Jaiswal, R.; Luchinat, C.; Nativi, C., Bioconjug. Chem. 2009, 20, 719-727.

34. Overall, C. M.; Lopez-Otin, C., Nat. Rev. Cancer 2002, 2, 657-672.

35. Dalvit, C.; Pevarello, P.; Tatò, M.; Veronesi, M.; Vulpetti, A.; Sundström, M., J. Biomol. NMR 2000, 18, 65-68.

36. Meyer, B.; Peters, T., Angew. Chem. Int. Ed. Engl. 2003, 42, $864-$ 890.

37. Feng, Y. Q.; Likos, J.; Zhu, L. M.; Woodward, H.; McDonald, J.; Stevens, A.; Howard, S.; Welsch, D., J. Biomol. NMR 2000, 17, 8586.

38. Rowsell, S.; Hawtin, P.; Minshull, C. A.; Jepson, H.; Brockbank, S.

15 M. V.; Barratt, D. G.; Slater, A. M.; McPheat, W. L.; Waterson, D.; Henney, A. M.; Pauptit, R. A., J. Mol. Biol. 2002, 319, 173-181.

39. Gasteiger, J.; Rudolph, C.; Sadowski, J., Tetrahedron Comp. Methodol. 1990, 3, 537-547.

40. Gasteiger, J.; Marsili, M., Tetrahedron Lett. 1978, 19, 3181-3184.

20 41. Mohamadi, F.; Richards, N. G. J.; Guida, W. C.; Liskamp, R.; Lipton, M.; Caufield, C.; Chang, G.; Hendrickson, T.; Still, W. C., J. Comp. Chem. 1990, 11, 440-467.

42. Chang, G.; Guida, W. C.; Still, W. C., J. Am. Chem. Soc. 1989, 111, 4379-4386.

25 43. Still, W. C.; Tempczyk, A.; Hawley, R. C.; Hendrickson, T., J. Am. Chem. Soc. 1990, 112, 6127-6129.

44. Polak, E.; Ribiere, G., Revue Française d'Informatique et de la Recherche Opérationnelle 1969, 16-R1.

45. Petitjean, M., Comput. Chem. 1998, 22, 463-465.

30 46. Morris, G. M.; Goodsell, D. S.; Halliday, R. S.; Huey, R.; Hart, W. E.; Belew, R. K.; Olson, A. J., J. Comp. Chem. 1998, 19, 1639-1662.

47. Stote, R. H.; Karplus, M., Proteins 1995, 23, 12-31.

48. GRID v. 22a. Molecular Discovery Ltd., 215 Marsh Road, Pinner, Middlesex, UK, 2004.

35 49. Glide v 2.5021. Schrödinger, L.L.C., New York, USA, 2003.

50. Friesner, R. A.; Banks, J. L.; Murphy, R. B.; Halgren, T. A.; Klicic, J. J.; Mainz, D. T.; Repasky, M. P.; Knoll, E. H.; Shelley, M.; Perry, J. K.; Shaw, D. E.; Francis, P.; Shenkin, P. S., J. Med. Chem. 2004, 47, 1739-1749.

40 51. Halgren, T. A.; Murphy, R. B.; Friesner, R. A.; Beard, H. S.; Frye, L. L.; Pollard, W. T.; Banks, J. L., J. Med. Chem. 2004, 47, 1750-1759.

52. Friesner, R. A.; Murphy, R. B.; Repasky, M. P.; Frye, L. L.; Greenwood, J. R.; Halgren, T. A.; Sanschagrin, P. C.; Mainz, D. T., J. Med. Chem. 2006, 49, 6177-6196.

45 53. Alberts, I. L.; Nadassy, K.; Wodak, S. J., Protein Sci. 1998, 7, 1700 1716.

54. Hu, X.; Balaz, S.; Shelver, W. H., J. Mol. Graph. Model. 2004, 22, 293-307.

55. Bayly, C. I.; Cieplak, P.; Cornell, W.; Kollman, P. A., J. Phys. Chem. 1993, 97, 10269 - 10280.

56. Frisch, M. J.; Trucks, G. W.; Schlegel, H. B.; Scuseria, G. E.; Robb, M. A.; Cheeseman, J. R.; Montgomery, J., J. A.; Vreven, T.; Kudin, K. N.; Burant, J. C.; Millam, J. M.; Iyengar, S. S.; Tomasi, J.; Barone, V.; Mennucci, B.; Cossi, M.; Scalmani, G.; Rega, N.; Petersson, G. A.; Nakatsuji, H.; Hada, M.; Ehara, M.; Toyota, K.; Fukuda, R.; Hasegawa, J.; Ishida, M.; Nakajima, T.; Honda, Y.; Kitao, O.; Nakai, H.; Klene, M.; Li, X.; Knox, J. E.; Hratchian, H. P.; Cross, J. B.; Bakken, V.; Adamo, C.; Jaramillo, J.; Gomperts, R.; Stratmann, R. E.; Yazyev, O.; Austin, A. J.; Cammi, R.; Pomelli, C.; Ochterski, J. W.; Ayala, P. Y.; Morokuma, K.; Voth, G. A.; Salvador, P.; Dannenberg, J. J.; Zakrzewski, V. G.; Dapprich, S.; Daniels, A. D.; Strain, M. C.; Farkas, O.; Malick, D. K.; Rabuck, A. D.; Raghavachari, K.; Foresman, J. B.; Ortiz, J. V.; Cui, Q.; Baboul, A. G.; Clifford, S.; Cioslowski, J.; Stefanov, B. B.; Liu, G.; Liashenko,

65 A.; Piskorz, P.; Komaromi, I.; Martin, R. L.; Fox, D. J.; Keith, T.; AlLaham, M. A.; Peng, C. Y.; Nanayakkara, A.; Challacombe, M.; Gill, P. M. W.; Johnson, B.; Chen, W.; Wong, M. W.; Gonzalez, C.; Pople, J. A. Gaussian 03, Revision C.02, Gaussian, Inc., Wallingford CT, 2004

70 57. Case, D. A.; Darden, T. A.; Cheatham, T. E., III; Simmerling, C. L.; Wang, J.; Duke, R. E.; Luo, R. E.; Merz, K. M.; Pearlman, D. A.;
Crowley, M.; Walker, R. C.; Zhang, W.; Wang, B.; Hayik, S.; Roitberg, A.; Seabra, G.; Wong, K. F.; Paesani, F.; Wu, X.; Brozell, S.; Tsui, V.; Gohlke, H.; Yang, C.; Tan, J.; Mongan, J.; Hornak, V.; Cui, G.; Beroza, P.; Mathews, D. H.; Schafmeister, C.; Ross, W. S.; Kollman, P. A. AMBER 9, University of California, San Francisco, 2006.

58. Darden, T. A.; York, D.; Pedersen, L. G., J. Chem. Phys. 1993, 98, 10089-10092.

80 59. Weingarten, H.; Feder, J., Anal. Biochem. 1985, 147, 437-440.

60. Weingarten, H.; Martin, R.; Feder, J., Biochemistry-Moscow 1985, 24, 6730-6734.

61. MacPherson, L. J.; Bayburt, E. K.; Capparelli, M. P.; Carroll, B. J.; Goldstein, R.; Justice, M. R.; Zhu, L.; Hu, S.; Melton, R. A.; Fryer,

85 L.; Goldberg, R. L.; Doughty, J. R.; Spirito, S.; Blancuzzi, V.; Wilson, D.; O'Byrne, E. M.; Ganu, V.; Parker, D. T., J. Med. Chem. 1997, 40, 2525-2532. 